\title{
BODY STRUCTURE MODEL CHARACTERISTICS IN FEMALE STUDENTS OF FACULTY OF SPECIAL EDUCATION AND REHABILITATION (FASPER) MEASURED BY THE METHOD OF MULTICANAL BIOELECTRIC IMPEDANCE
}

\author{
CARACTERÍSTICAS DE MODELO DE LA ESTRUCTURA CORPORAL \\ DE LAS ESTUDIANTES DE LA FACULTAD DE EDUCACIÓN ESPECIAL \\ Y REHABILITACIÓN (FASPER) MEDIDAS POR EL MÉTODO DE \\ IMPEDANCIA BIOELÉCTRICA MULTICANAL
}

\author{
Milivoj Dopsaj ${ }^{1,4}$, Eminović Fadilj², Đorđević-Nikić Marina ${ }^{1}$, Dragan Miljuš³ ${ }^{3}$ Goran Kasum ${ }^{1}$ \\ ${ }^{1}$ Faculty of Sport and Physical Education, University of Belgrade, Serbia \\ ${ }^{2}$ Faculty for Special Education and Rehabilitation (FASPER), University of Belgrade, Serbia \\ ${ }^{3}$ Institute of Public Health of the Republic of Serbia "Dr Milan Jovanovic Batut", Belgrade, Serbia \\ ${ }^{4}$ Institute of Sport, Tourism and Service, South Ural State University, Chelyabinsk, Russia
}

\begin{abstract}
The goal of this research was to define the initial body structure model of female students of Faculty of Special Education and Rehabilitation (FASPER), University of Belgrade, as a person whose professional and work commitment is working with disabled people and it's perceived as a very responsible, stressful and atypical work profile. The sample was made of 125 participants (female students) of III and IV year of Bachelor studies of FASPER. Research was conducted in a Methodical-research laboratory (MRL) in Faculty of sport and physical education, University of Belgrade in a time period 2012-2017, in accordance with standardized procedure of applying electrical multichannel bioimpedance method with body structure analyzer-InBody 720. It contained twenty (20) variables, eight (8) were basic and twelve (12) were derived. Based on BMI it's claimed that $77.60 \%$ participants has a normal body status, but the prevalence of overweight students $(\mathrm{BMI}<25.00)$ were $7.20 \%$, apropos the prevalence of obesity $(\mathrm{BMI}<30.00)$ was $4.00 \%$. It's also established that the prevalence of underweight students $(\mathrm{BMI}>18.50)$ is $11.20 \%$, with $4.00 \%$ participants who were significantly thinness underweight i.e. poorly nourished (BMI $>17.50)$. According to the results it was concludet that even $96.8 \%$ of sample was not in line with ideal or optimal body structure profile. For example, 63.2\% participants has some form of body mass deficits (average of $5.25 \mathrm{~kg}$ ) with mostly muscle component deficit $78.4 \%$ (average muscle mass deficit is $4.28 \mathrm{~kg}$ ) and with body fat component deficit $43.2 \%$ (average deficit of body fat is $2.01 \mathrm{~kg}$ ). On the other hand, $33.6 \%$ participants has a form of surplus (average surplus
\end{abstract}

\begin{abstract}
EXTRACTO
El objetivo de la investigación es definir las características de modelo de la estructura corporal de las estudiantes de la FASPER de la Universidad en Belgrado, como personas cuya orientación laboral futura es el trabajo con las personas inválidas, lo que representa un perfil laboral profesional muy responsable, estresado y atípico. La muestra ha sido compuesta de las 125 examinadas. Las mediciones se han hecho en el Laboratorio metódico-investigativo de la Facultad de Deporte y Educación Física de la Universidad en Belgrado, utilizando el analizador de la estructura corporal - InBody 720. La investigación ha abarcado veinte (20) variables. Los resultados han mostrado que los 77,60 $\%$ de las examinadas están en el estatus de nutrición normal, que la prevalencia de las examinadas con sobrepeso $(\mathrm{BMI}<25.00)$ es el 7,20\%, es decir, con obesidad (BMI<30.00) el $4.00 \%$. También se ha establecido que la prevalencia de desnutrición (BMI< $18.50 \%$ ) es el $11,20 \%$, donde incluso el $4,00 \%$ de las examinadas es considerablemente desnutrido $(\mathrm{BMI}<17.50 \%)$. Los resultados demostraron que incluso los $96.8 \%$ de las examinadas se desvían del perfil de la nutrición ideal. En relación con la desviación hacia el déficit, los $63 \%$ de las examinadas tiene alguna forma de déficit de la masa corporal (el promedio del déficit de la masa corporal es de $5.20 \mathrm{~kg}$ ) y la mayoría de ellas tiene el déficit del componente de músculos los 78,4\% (el déficit de $4.28 \mathrm{~kg}$ ), así como también en relación con el déficit de componente graso los $43,2 \%$ (déficit de $2.01 \mathrm{~kg}$ ). Con el perfil de alguno de los excedentes están los $33,6 \%$ de las examinadas (excedente de la masa corporal de 9.44 $\mathrm{kg}$ ), donde incluso los 54,4\% tiene el excedente del componente
\end{abstract}


in body structure is $9.44 \mathrm{~kg}$ ) where even $54.4 \%$ has a surplus of body fat component (average level of surplus of body fat 7.48 $\mathrm{kg}$ ). The results of $4 \mathrm{D}$ body structure model of female students from FASPER can be defined like this: $31.77 \mathrm{~L}$ of Total Body Water (53.37\%), $8.50 \mathrm{~kg}$ of proteins (14.26\%), $16.98 \mathrm{~kg}$ of body fat $(27.10 \%)$ and $3.10 \mathrm{~kg}$ of minerals $(5.18 \%)$. Beside the probability that the reason of bad nutrition behaviour of these students is the cause of their increasing fat depots it's also a fact that $69.6 \%$ of these students are physically inactive and $21.6 \%$ just occasionally active, which mean that $91.2 \%$ of students was physically non active pearson, could indicate a most possible reason of body fat componente suficit and body muscle componente deficit as a main body structure characteristics.

Key word: PERCENT OF BODY FAT / PERCENT OF MUSCLE MASS / FEMALE STUDENTS, BODY COMPOSITION / UNIVERSITY OF BELGRADE

\section{INTRODUCTION}

Besides basic morphological characteristics, body height (BH) and body weight (BW), the human body has its own structure. The term body structure defines the composition and interaction of all organic tissues, as a biological set of substances, of which the human organism consists (Heyward \& Stolarczyk, 1996).

At the macro level, the human organism consists of four basic elements (segments), as the main biologically measurable substances: water, oily, protein and mineral component. Mathematically, the relations of these basic elements define morphological indices, based on which the representation of individual elements in the body is calculated, which determines the proportions or body structure (Heyward and Stolarczyk, 1996; Dopsaj et al., 2013; Dopsaj et al., 2015). The given data is of crucial importance for clinical practice and defining the state of nutrition of individual, but also they are changeable that is variables of interest for scientific research in applied anthropology (pedagogical, medical, cultural, evolutionary, etc.) (Mott et al., 1999; WHO, 2000; Kyle et al., 2006; Stommel and Schoenborn, 2010).

Students represent a population of people of greatest interest to a society, because they are the carriers of the development of that same society in the immediate, close and distant future. This particularly applies to female students of the Faculty of Special Education and Rehabilitation (FASPER) because they are trained for high profile professions who will during their working age deal with people with a certain degree and type of disability. In other words, a professional work profile will have work graso (excedente de $7.48 \mathrm{~kg}$ ). Además de la probabilidad que la forma de nutrición es la razón para el aumento del componente graso y el hecho que incluso los $69,6 \%$ de las examinadas no están físicamente activas de manera adecuada, los $21.6 \%$ solo de vez en cuando, es decir los $91.2 \%$ en total, indica la posible razón porque en ellas se ha encontrado el excedente del componente graso y el déficit del componente muscular.

Palabras claves: PORCENTAJE DE GRASA / PORCENTAJE DE MÚSCULOS / LAS ESTUDIANTES / COMPOSICIÓN CORPORAL / UNIVERSIDAD EN BELGRADO

characteristics in terms of permanent exposure to stressful situations in relation to activities and specific forms of work and treatment with people with speech disorders, language and communication, visual disturbance, hearing, social behavior, as well as various psychological, physical and muscular-neural deficits. Permanent exposure to such professional work agents increases the risk of excessive negative cumulative impact in terms of health, physical and / or physical status for the future.

The monitoring of habits in physical activity, eating habits, as well as conditions and changes in body status since school days, and even during the student period, is a very important procedure because it provides initial information about the research area, that is, determines the facts about the current morphological status from the beginning of the education period, (Hoffman et al., 2006; Dopsay et al., 2010; Meckel et al., 2011; Hajnalka \& Chaba, 2017). In addition to personal socio-social and professional changes that a student population meet in the near future, there are inevitable biological influences that are taking place during growing up and aging, and which modern life and urbanization bring about as a change in the lifestyle of a modern man. Two basic factors of modern lifestyle are reduced physical activity and increased energy intakes, have caused a phenomenon that manifests itself through an enormous increase in the prevalence of obesity, that is, persons with an increased percentage of body fat. The phenomenon became the main determinant of increasing the incidence of non-contagious diseases 
in a modern man (WHO, 2000).

So far, the measurement procedures and procedures in the field of body composition, as well as the degree of nutrition and morphological characteristics in humans, were predominantly based on the Body Mass Index (BMI), that is the measurement of skin folds and / or the volume of different body extremities, and the use given data in terms of their conversion for the needs of estimating certain structural elements using mathematical formulas (Heyward and Stolarczyk, 1996). However, it has been established that this kind of evaluation has major predicament errors, while for BMI it is increasingly confirmed that it is not sufficiently specific and sensitive in the dressed value zones in the function of prediction of the real values of the body composition, and especially in relation to the level of fat in the body (Kyle et al., 2003; Rothma, 2008).

The instruments of the latest generation measuring that use the new body metering technology use the principle of multichannel electrical bioimpedance and with high reliability and measurement fluency provide valid scientific data on the content and structure of the body (InBody 720, 2005; Dopsaj et al., 2017).

The aim of this research is to define the characteristics of the model of the body structure in female students of FASPER University in Belgrade. The analytical and diagnostic aspect of the obtained results will indicate the current level of quantitative characteristics of the observed body space in future professionals working with disabled persons, that is, as women in the work with disabled people. Also, the obtained results will point to the current profile of the body structure in young girls of academic orientation as part of the university population of Belgrade, oriented towards the socio-humanistic profile of education.

\section{METHODS}

This research is non-experimental in character, while in relation to the type belongs to the descriptiveanamnestic study.

\section{Sample}

The sample consisted of 125 students of the III and IV year of basic graduate studies at the FASPER University of Belgrade. The basic descriptive data on subjects were: age $=22.5 \pm 1.9$ years, $\mathrm{BH}=166.7$ $\pm 6.5 \mathrm{~cm}, \mathrm{BW}=60.3 \pm 12.1 \mathrm{~kg}$. In relation to the frequency of physical activity (walking) or physical exercise (sports training, organized or independent recreation or fitness), 87 respondents (69.6\%) were not physically active at all or did not practice, that is they had a sedentary lifestyle, 27 respondents (21.6\%) were physically active or occasionally exercised (2-3 times a week), 7 subjects (5.6\%) were physically active or exercised regularly (4-5 times a week) and only 4 subjects $(3.2 \%)$ were intensely physically active, that is they practiced intensively (more than 6 times a week). In relation to respondents who were physically active or exercised, the average single daily activity / exercise lasted $49.2 \pm 20.2$ minutes, or viewed on a weekly basis, the activity / exercise duration was $147.3 \pm 126.6$ minutes.

\section{Measurement of body structure}

All measurements were made at the Methodological-research laboratory (MRL) of the Faculty of Sport and Physical Education of the University of Belgrade in the period from 2012 to 2017 in the morning hours between 09:00 and 11:00. Measurements were conducted in accordance to a standardized procedure (at least 24 hours before the measurement consumption of alcohol and physical exercise were prohibited, at least 2 hours before measurement it was forbidden to take food and water, at least 5 minutes before the measurement, all respondents stood and the measurement was achieved in lightweight sports clothes, at least 30 minutes before the measurements were completed, physiological discharge was completed, and during the measurement, nobody had anything metal) using the method of electrical multichannel bioimpedance with body structure analyzer of the latest generation InBody 720 (InBody 720, 2005). 


\section{Variables}

This study covers twenty (20) variables, eight (8) basic and twelve (12) derived; that is, index variables, which define the characteristics of the model of the body structure of the examinees.

The basic variables were as follows:

1. $\mathrm{BH}$ - body height, expressed in $\mathrm{cm}$,

2. BW - body weight, expressed in $\mathrm{kg}$,

3. FFM - fat free mass, expressed in $\mathrm{kg}$,

4. Proteins - mass of proteins in the body, expressed in $\mathrm{kg}$,

5. Minerals - total weight of minerals in the body, expressed in $\mathrm{kg}$,

6. BF - total body fat, expressed in $\mathrm{kg}$,

7. SMM - Skeletal Muscle Mass, expressed in kg,

8. VFA - Visceral Fat Area, expressed in $\mathrm{cm} 2$.

Derived (index) variables were as follows:

1. BMI - Body Mass Index, expressed in $\mathrm{kg} \cdot \mathrm{m}^{-2}$,

2. Targ_BM - ideal body weight (Target BM), expressed in $\mathrm{kg}$,

3. W_Control - recommended corrections of the actual body weight (Weight Control), expressed in kg,

4. F_Control - recommended body fat correction (Fat Control), expressed in kg,

5. M_Control - recommended correction of skeletal muscle mass (Muscle Control), expressed in $\mathrm{kg}$,

6. Fitness_Skor - quantitative (numerical) assessment of body status, expressed in a scorecard,

7. PBF - percentage of body fat (Percent of Body Fat Mass), expressed in $\%$

8. PSMM - percentage of skeletal muscle in the body, expressed in $\%$,
9. FMI - Fat Mass Index, expressed in $\mathrm{kg} \cdot \mathrm{m}^{-2}$,

10. SMMI - skeletal muscle mass index, expressed in $\mathrm{kg} \cdot \mathrm{m}^{-2}$,

11. FFMI - Fat Free Mass Index, expressed in kg. $\mathrm{m}^{-2}$,

12. PFI - relation between Protein and Fat mass (Protein Fat Index), expressed in kg.

\section{Statistical data processing}

All raw results are inserted into the standard EXCEL software in order to form a database and perform a logical test of the results. After logical checks, using the descriptive statistical procedures, the necessary parameters of the central tendency and dispersion of data were calculated (Mean, SD, cV\%, Std. Error, Skewness, Kurtosis, Min, Max and confidence interval to $95 \%$ ). The regularity of the distribution of variables was checked using the nonparametric test Kolmogorov-Smirnov (KSZ), while the distribution values were defined using percentile. For all statistical procedures, the software package SPSS Statistics 17.0 (Hair et al., 1998) was used.

\section{RESULTS}

The basic descriptive statistics of the examined body structure variables are shown in Table 1. Table 2 gives the results of the percentile distribution of all tested variables defined in relation to nine characteristic classes of results $(2.5,5.0,10.0,25.0$, 50.0, 75.0, 90.0, 95.0 and 97.5 percentil). 
Table 1. Basic descriptive statistics of studied variables

\begin{tabular}{|c|c|c|c|c|c|c|c|c|c|c|}
\hline \multirow{2}{*}{ Varijabla } & \multirow{2}{*}{ Mean } & \multirow{2}{*}{ SD } & \multirow{2}{*}{ cV\% } & \multirow{2}{*}{$\begin{array}{l}\text { Std. } \\
\text { Error }\end{array}$} & \multirow{2}{*}{ Skew } & \multirow{2}{*}{ Kurt } & \multirow{2}{*}{ Min } & \multirow{2}{*}{ Max } & \multicolumn{2}{|c|}{$\begin{array}{l}\text { 95\% Conf. } \\
\text { Interval }\end{array}$} \\
\hline & & & & & & & & & $\begin{array}{l}\text { Lower } \\
\text { Bound }\end{array}$ & $\begin{array}{l}\text { Upper } \\
\text { Bound }\end{array}$ \\
\hline TV $(\mathbf{c m})$ & 166.7 & 6.5 & 3.9 & 0.58 & 0.24 & -0.01 & 151.7 & 185.7 & 165.5 & 167.8 \\
\hline TM (kg) & 60.31 & 12.11 & 20.1 & 1.1 & 2.17 & 6.73 & 44.4 & 114.7 & 57.2 & 62.5 \\
\hline BMI $\left(\mathrm{kg} \cdot \mathrm{m}^{-2}\right)$ & 21.67 & 3.87 & 17.9 & 0.35 & 2.19 & 6.44 & 16.19 & 39.18 & 20.99 & 22.36 \\
\hline FFM (kg) & 43.24 & 5.13 & 11.9 & 0.46 & 0.84 & 1.85 & 33.20 & 61.94 & 42.34 & 44.15 \\
\hline Proteini (kg) & 8.47 & 0.98 & 11.6 & 0.09 & 0.68 & 1.16 & 6.60 & 11.80 & 8.29 & 8.64 \\
\hline Minerali (kg) & 3.08 & 0.41 & 13.3 & 0.04 & 1.05 & 2.62 & 2.20 & 4.64 & 3.01 & 3.15 \\
\hline BF (kg) & 17.00 & 8.27 & 48.7 & 0.74 & 2.46 & 7.48 & 7.40 & 53.70 & 15.53 & 18.46 \\
\hline SMM (kg) & 23.54 & 2.98 & 12.7 & 0.27 & 0.69 & 1.19 & 18.00 & 33.70 & 23.02 & 24.07 \\
\hline VFA $\left(\mathrm{cm}^{2}\right)$ & 47.75 & 29.31 & 61.4 & 2.62 & 1.93 & 4.64 & 9.50 & 168.0 & 42.56 & 52.94 \\
\hline Targ_TM (kg) & 60.47 & 5.38 & 8.9 & 0.48 & 0.90 & 2.14 & 49.50 & 80.50 & 59.52 & 61.43 \\
\hline W_control (kg) & 0.16 & 9.26 & 5787.0 & 0.83 & -1.77 & 4.31 & -38.70 & 14.60 & -1.48 & 1.80 \\
\hline F_control (kg) & -3.20 & 7.73 & 241.6 & 0.69 & -2.27 & 6.44 & -38.70 & 6.00 & -4.57 & -1.83 \\
\hline M_control (kg) & 3.36 & 2.87 & 85.4 & 0.26 & 0.60 & -0.18 & 0.00 & 13.00 & 2.85 & 3.87 \\
\hline Fitness_Score (bod) & 72.24 & 5.63 & 7.8 & 0.50 & -1.10 & 2.36 & 48.00 & 83.00 & 71.24 & 73.24 \\
\hline Proc_BF (\%) & 26.14 & 6.87 & 26.3 & 0.61 & 1.10 & 0.92 & 16.48 & 51.59 & 25.92 & 28.36 \\
\hline Proc_SMM (\%) & 39.57 & 3.70 & 9.4 & 0.33 & -0.99 & 0.62 & 26.90 & 45.43 & 38.91 & 40.22 \\
\hline FMI $\left(\mathbf{k g} \cdot \mathbf{m}^{-2}\right)$ & 6.11 & 2.87 & 47.0 & 0.27 & 2.34 & 6.98 & 2.74 & 20.21 & 5.60 & 6.61 \\
\hline SMMI $\left(\mathbf{k g} \cdot \mathbf{m}^{-2}\right)$ & 8.46 & 0.82 & 9.7 & 0.07 & 0.56 & 0.65 & 6.71 & 11.00 & 8.32 & 8.61 \\
\hline FFMI $\left(\mathbf{k g} \cdot \mathbf{m}^{-2}\right)$ & 15.55 & 1.36 & 8.8 & 0.12 & 0.67 & 1.25 & 12.63 & 20.23 & 15.30 & 15.79 \\
\hline PFI (kg) & 0.567 & 0.168 & 29.6 & 0.015 & -0.07 & -0.39 & 0.184 & 1.000 & 0.536 & 0.596 \\
\hline
\end{tabular}

Based on the results shown in Table 1, it can be claimed that the variation coefficient values $(\mathrm{cV} \%)$ in the following variables are above the limits for a homogeneous set: total body mass, BF - 48.7\%, visceral fat surface, VFA - $61.4 \%$ recommended reduction of the body weight, W_control - 5787.0\%, recommended weight body reduction, F_control $241.6 \%$, recommended muscle weight reduction, $\mathrm{M}_{-}$ control - 85.4\%, and body fat index, FMI - 47.0\%. The remaining fourteen variables have characteristics of a homogeneous set, since the values of the coefficient of variation are below the limit value, or less than $30.0 \%$.
Based on the measure of flattening and curvature of the distribution of results, it can be claimed that in seven variables there is an emphasized platitude of the distribution of the same (TM, BMI, BF, VFA, W_ control, F_control and FMI), that is, the measured respondents are less distributed in the zone of the average but the distribution form is asymmetric screwed to higher values of variables. At the same time, it means that for all the above mentioned variables most of the measured values of the examinees are concentrated at lower values. 
Table 2. Results of percentile distribution of all tested variables

\begin{tabular}{|c|c|c|c|c|c|c|c|c|c|}
\hline \multirow{2}{*}{ Varijable } & \multicolumn{9}{|c|}{ Percentili (\%o) } \\
\hline & 2.5 & 5 & 10 & 25 & 50 & 75 & 90 & 95 & 97.5 \\
\hline TV (cm) & 153.7 & 155.7 & 159.0 & 162.0 & 166.1 & 170.5 & 175.6 & 177.3 & 181.3 \\
\hline TM (kg) & 44.6 & 45.6 & 48.6 & 53.6 & 58.0 & 64.1 & 73.6 & 83.6 & 102.8 \\
\hline BMI $\left(\mathbf{k g} \bullet \mathbf{m}^{-2}\right)$ & 16.66 & 17.57 & 18.21 & 19.43 & 20.84 & 22.49 & 27.20 & 29.59 & 36.45 \\
\hline FFM (kg) & 34.66 & 35.76 & 36.84 & 39.37 & 43.11 & 46.30 & 49.43 & 51.24 & 57.45 \\
\hline Proteini (kg) & 6.80 & 7.00 & 7.20 & 7.70 & 8.50 & 9.00 & 9.70 & 9.97 & 11.18 \\
\hline Minerali (kg) & 2.42 & 2.52 & 2.55 & 2.80 & 3.02 & 3.26 & 3.49 & 3.79 & 4.26 \\
\hline BF (kg) & 7.71 & 9.63 & 10.80 & 12.00 & 14.30 & 19.35 & 27.78 & 31.88 & 50.64 \\
\hline SMM (kg) & 18.42 & 19.03 & 19.76 & 21.25 & 23.70 & 25.30 & 27.14 & 28.07 & 31.73 \\
\hline VFA $\left(\mathrm{cm}^{2}\right)$ & 11.59 & 15.04 & 19.36 & 29.80 & 40.90 & 58.65 & 82.28 & 108.31 & 155.09 \\
\hline Targ_TM (kg) & 50.8 & 52.2 & 54.3 & 56.8 & 60.2 & 63.3 & 66.8 & 69.8 & 74.9 \\
\hline W_control (kg) & -32.7 & -17.6 & -13.4 & -2.6 & 2.0 & 5.7 & 8.7 & 11.4 & 13.0 \\
\hline F_control (kg) & -32.7 & -17.6 & -13.7 & -6.2 & -0.4 & 1.3 & 3.1 & 4.0 & 5.0 \\
\hline M_control (kg) & 0.0 & 0.0 & 0.0 & 0.8 & 3.3 & 5.1 & 7.5 & 8.3 & 8.7 \\
\hline Fitness_Score (bod) & 57.0 & 62.0 & 66.0 & 69.0 & 73.0 & 76.0 & 78.0 & 79.0 & 81.7 \\
\hline Proc_BF (\%) & 17.2 & 19.7 & 20.4 & 22.1 & 25.0 & 31.3 & 37.4 & 40.6 & 45.8 \\
\hline Proc_SMM (\%) & 29.6 & 32.4 & 34.4 & 37.1 & 40.7 & 42.4 & 43.3 & 43.8 & 44.8 \\
\hline FMI $\left(\mathbf{k g} \cdot \mathbf{m}^{-2}\right)$ & 3.00 & 3.61 & 3.83 & 4.38 & 5.09 & 7.12 & 10.03 & 11.89 & 16.68 \\
\hline SMMI $\left(\mathbf{k g} \cdot \mathbf{m}^{-2}\right)$ & 7.13 & 7.22 & 7.38 & 7.96 & 8.37 & 8.88 & 9.53 & 9.88 & 10.53 \\
\hline FFMI $\left(\mathbf{k g} \bullet \mathbf{m}^{-2}\right)$ & 13.31 & 13.53 & 13.76 & 14.74 & 15.34 & 16.28 & 17.22 & 17.75 & 18.92 \\
\hline PFI (kg) & 0.23 & 0.29 & 0.33 & 0.43 & 0.59 & 0.69 & 0.77 & 0.80 & 0.94 \\
\hline
\end{tabular}

Figure 1 shows the distribution of respondents in relation to the variables that define the general nutritional status (BMI).

Based on BMI distribution, it can be argued that $77.60 \%$ of subjects are in normal nutritional status (Table 1, BMI from 18.50 to 24.99), but that prevalence of subjects with overweight $(\mathrm{BMI}=25.00$ to 29.99 ) is $7.20 \%$, that is prevalence of obesity (BMI $<30.00) 4.00 \%$. It was also found that the overall prevalence of insufficient nutrition $(B M I \geq 18.49)$ was $11.20 \%$, where as much as $4.00 \%$ of subjects were significantly unfed (BMI $\geq 17.49$ ).

Figure 2 shows the results of the prevalence of respondents classified in relation to the three categories: subjects with some deficit or surplus of the morphological component that is respondents with optimal body status.

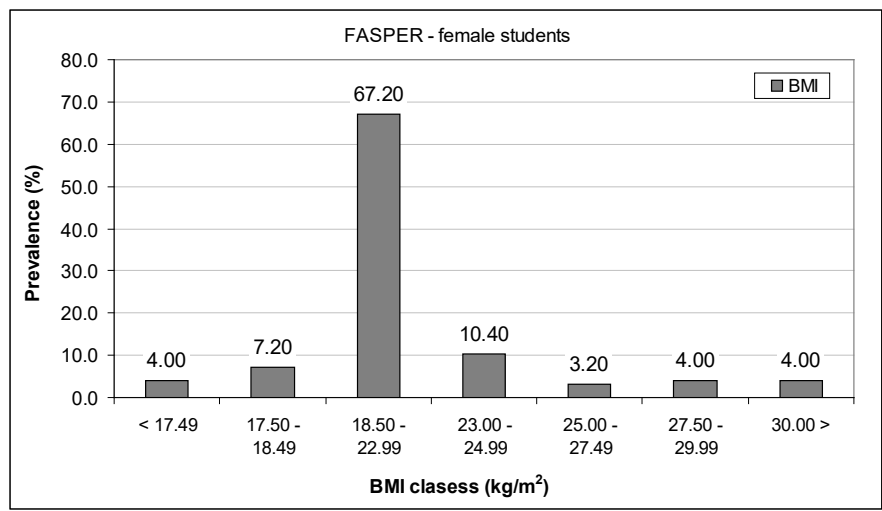

Figure 1. Distribution of respondents in relation to BMI defined according to WHO criteria (subclass category) 


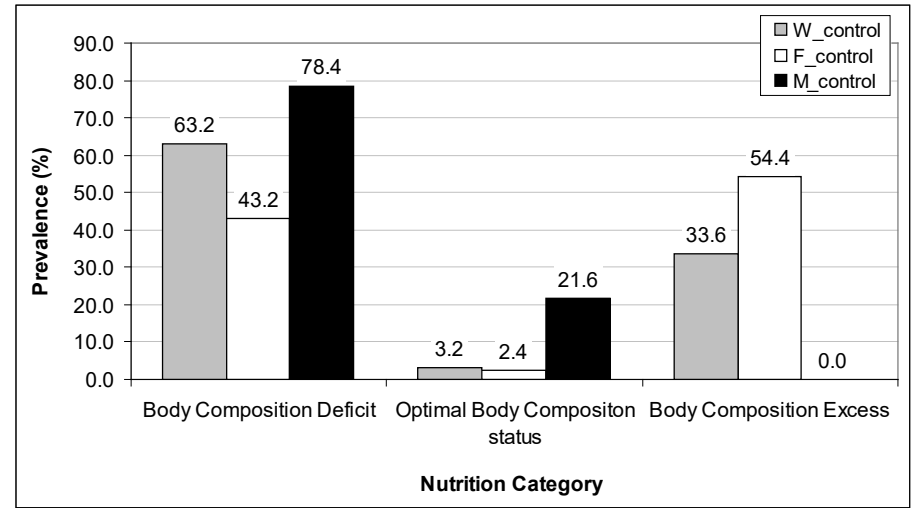

Figure 2. Prevalence of subjects classified in relation to three categories: respondents with some of the deficit or surplus of the morphological component and respondents with optimal body status

The results of the prevalence of deficiencies of various morphological components (Figure 2) showed that there is a higher incidence of deficiency, than the frequency of the surplus, that is, respondents with optimal body status. It is generally established that even $63.2 \%$ of subjects have some form of deficiency in weight (W_control, weight deficiency average of $5.20 \mathrm{~kg}$ ), with the highest deficiency of muscular component $78.4 \%$ (M_control, average of $4.28 \mathrm{~kg}$ muscle mass deficit), i.e. deficiency of the mass component $43.2 \%$ (F_control, average weight deficit of $2.01 \mathrm{~kg}$ ). In comparison to the surplus, $33.6 \%$ of the subjects have a certain surplus (W_control, with an average body weight of $9.44 \mathrm{~kg}$ ), where even $54.4 \%$ have a surplus fat component $\left(\mathrm{F}_{-}\right.$

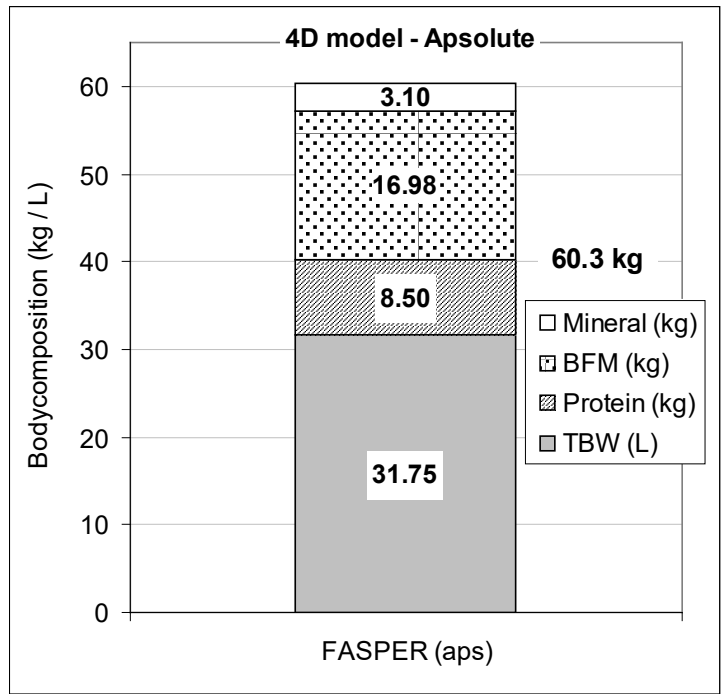

control, at an average level of a weight of $7.48 \mathrm{~kg}$ ). In the overall study sample, only $3.2 \%$ of respondents had an optimal body structure, of which only $2.4 \%$ compared to fat, and $21.6 \%$ relative to the muscle component.

Figure 3 shows the results of the defined 4D model of body structure of FASPER student measured by the multichannel bioelectric impedance method. The model is presented in absolute $(\mathrm{kg})$ and relative (\% of $\mathrm{BM})$ values.

The results of the 4D models of the body structure of the examined students can be defined as follows: $31.75 \mathrm{~L}$ of water $(53.37 \%), 8.50 \mathrm{~kg}$ of protein $(14.26 \%)$, $16.98 \mathrm{~kg}$ of fat $(27.10 \%)$ and $3.10 \mathrm{~kg}$ of minerals (5.18\% of TM).

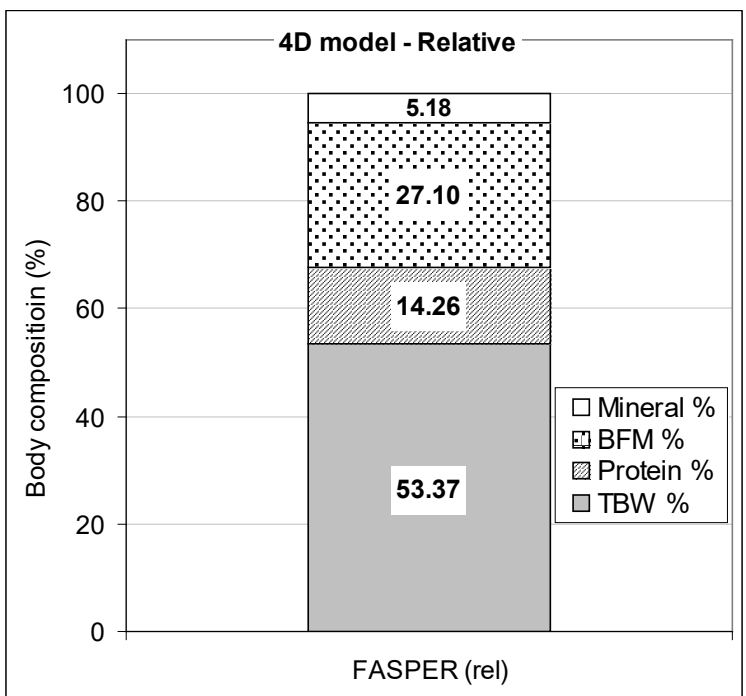

Figure 3. The results of the defined $4 \mathrm{D}$ model (absolute, in $\mathrm{kg}$, and relative, in $\%$ of $\mathrm{BM}$ ) of the body structure of FASPER student measured by the method of multichannel bioimpedance. 


\section{DISCUSSION}

Modern society implies constant technological advancement, that is, it has a constant need to innovate all the necessary knowledge and knowledge, which depends on social progress. Part of the given technology of progress can also be recognized in the need for continuous collection of information on the characteristic and important parts of society, in which the quality of life, with all its positive and negative sides makes an important segment (WHO, 2000). In this way, a permanent information base is provided, which forms the basis for decision making in terms of planning, programming and correction of the existing system of organization of society in accordance with future and contemporary needs (Dopsaj et al., 2010).

The body structure in humans, or morphological space as a term, implies a field of research in a science that studies the shape and composition of the body, and studies the basic dimensions that describe given form and composition (Heyword and Stolarczyk, 1996). In relation to the mentioned biological system and the various components from which the human body is composed, the body status ie, the status of nutrition is a biologically extremely adaptive characteristic and depends directly on the ratio of calorie intake and calorie consumption. In other words, the physical status is directly subject to changes that depend on the diet, lifestyle and habits of physical exercise, both positive and negative (WHO, 2000; Kyle et al., 2006; Hull et al., 2007).

From the aspect of the standards of healthy and young people in the Republic of Serbia, it can be confirmed that in comparison to the $\mathrm{BH}$, the sample of FASPERA students is on the 20th percentile, which means that the students belong to the category below the average high female persons (Dopsaj et al., 2010, p. 202-204). In comparison to BM and BMI, the sample tested is with $60.31 \mathrm{~kg}$ and $21.67 \mathrm{~kg} \cdot \mathrm{m}^{-2}$ of average values is in the category of average body weight and the category of average body weight index (Dopsaj et al., 2010, pp. 205-207).

According to the results of the study, which examined the morphological characteristics of physically active students of Belgrade University in 12 faculties, where in the total sample which represented $0.30 \%$ of the population there were 113 female students (Dopsaj et al., 2015) it is determined that the overall prevalence of overweight and obese student, defined by BMI, $10.30 \%$, while obesity is only $2.21 \%$. Also, the prevalence of insufficient nutrition was $3.68 \%$. Comparing these results, it can be argued that the overall prevalence of overweight and obesity in FASPERA students is somewhat higher than that of the University (11.20 vs $10.30 \%$, repetitive), but the prevalence of obesity is almost twice as high (4.00 versus $2.21 \%$, respectively). However, the prevalence of insufficiently nursed students in FASPER students is about 2.5 times higher than in students from the Belgrade University (11.20 vs. $3.68 \%$, respectively). In other words, the tested sample of FASPER students, comparing them to physically active students of the Belgrade University, shows the characteristics of bimodal nutrition, that is a tendency accentuated toward a 2.5 times higher prevalence of skinny and about 2 times greater prevalence of obese population.

In relation to other fat tissue components, physically active students of the Belgrade Faculty have a $14.71 \%$ less total amount of fat tissue $(\mathrm{BF})$, and $11.18 \%$ less internal fat and visceral fats (VFA), and 9.83\% less fat tissue than a tested sample of female FASPER students. These results indicate that in comparison to the mentioned fat components of the tested FASPERA students, they have all the indicators of fat, both absolute and relative, for about 10 to 15\% higher than physically active students of the Belgrade University (Dopsaj et al., 2015). In addition to the existing probability that the cause of increased fat depos in FASPER students is the nutrition, and the fact that even $69.6 \%$ are not at all physically active, and that $21.6 \%$ is only occasionally active, that is $91.2 \%$ is not adequately physically active, which indicates the reason why a fat content component is in surplus (Table 1).

Consequently, and in relation to students of BU that are physically active, in the tested sample, FASPERA female students research show completely inverted results in relation to the status of the contractile component. Namely, they had a 7.13\% less protein in the body (Protein), and even a $18.3 \%$ worse protein and fat index in the body (PFI) compared to physically active students of Belgrade University (Dopsaj et al., 2015).

If we compare the relative values of the body structure of the 4D model defined on both of these mentioned samples, FASPERA students had a 3.8\% lower percentage of total water in the body (53.37 vs $55.48 \%$, respectively), they had a $4.6 \%$ lower percentage of protein as contractile components in 
the body ( 14.26 vs $14.94 \%$, respectively) had a higher body fat percentage by $11.16 \%$ ( 27.10 vs. $24.28 \%$, respectively) and had a $2.5 \%$ lower body mineral (5.18 vs $5.31 \%$ ) compared to physically active student of the Belgrade University (Dopsaj et al., 2015).

The characteristic thing is that in comparison to the almost identical level of nutrition between the two analyzed samples (current study BMI $=21.67$, students of the University of Belgrade $21.71 \mathrm{~kg} \bullet \mathrm{m}^{-2}$ ), the sample of the FASPERA students had a reversely proportional different structure of the body, so there was a significant fat tissue surplus (absolutely $2.12 \mathrm{~kg}$ fat more), and at the same time a significant deficit of pure contractile, that is protein tissue (absolutely by $0.65 \mathrm{~kg}$ less, Table 1). Body status where BMI is in the zone of absolutely normal values, but where there is a surplus fat component and the contractual deficit is certainly not a desirable model of body structure, especially when it comes to young women, female students aged $22.5 \pm 1.9$ years.

Namely, it is determined that with the increase of the body mass index (BMI) that is body mass, at the expense of the fat component, the health risk for five chronic non-contagious diseases significantly increased, that are: high blood pressure, diabetes, chronic kidney disease, asthma and arthritis diseases. In previous studies, it was found that the prevalence of hypertension and arthritis in subjects with BMI values ranged from 24.0 to 25.0 at the level of 18.5 and 7.7, while in people with BMI values from 30.0 to 31.0 at the level of 30.7 and 11.7 respectively (Stommel and Schoenborn, 2010).

It has also been found that in BMI of female the BMI is growing by itself with age, increasing by a constant of $1.82 \mathrm{~kg} \cdot \mathrm{m}^{-2}$ per decade from 20 years to 50 years of age, that is, from an average value of $21.3 \pm 1.9 \mathrm{~kg} \bullet \mathrm{m}^{-2}$ grows to $27.5 \pm 4.6 \mathrm{~kg} \bullet \mathrm{m}-2$ in said age (Casey et al., 1992). The likelihood that a woman will have high BMI value will also increase statistically significant with age, so the correlation between BMI values between ages 50 and 20 at $r=0.44,50$ and 30 years at $r=0.80$ a 50 and 40 years at $r=0.87$ (Casey et al., 1992).

Very similar results were found by our researchers, because the results of the study dealing with basic morphological indicators of adults found that the BMI value in women from Vojvodina aged from 33.0 to 40.0 years is in the range of $25.67 \pm 4.51 \mathrm{~kg} \cdot \mathrm{m}^{-2}$, where the prevalence of overweight women is over $30.0 \%$, while prevalence of obesity exceeds $16.0 \%$ (Pavlica et al., 2008). Women from Belgrade, aged
$35.2 \pm 9.5$ years, were $167.04 \pm 6.62 \mathrm{~cm}$ tall, weighed $67.66 \pm 13.39 \mathrm{~kg}$, with BMI of $24.27 \pm 4.66 \mathrm{~kg} \cdot \mathrm{m}^{-2}$. The percentage of muscle mass in the mentioned sample was $29.09 \pm 8.47 \%$, while the percentage of fat tissue was $29.09 \pm 8.47 \%$, with the surface of visceral fat of $77.92 \pm 40.23 \mathrm{~cm}^{2}$. The results of the $4 \mathrm{D}$ model of the body composition were as follows: the weight of the water is $34.58 \mathrm{~L}$ or $51.11 \%$, the protein mass is $9.25 \mathrm{~kg}$ or $13.68 \%$, the weight of the minerals is 3.30 $\mathrm{kg}$ or $4.88 \%$, and the weight of the fat is $20.25 \mathrm{~kg}$ or $30.32 \%$. It was found that there is a high percentage of women in the pre-hospital and obese category and according to BMI (about 40.0\%), as well as according to Proc_BF (about 36\%) (Djordjevic-Nikic et al., 2013).

One American study dealing with changes in body structure in first-year students showed that, despite excellent conditions for physical exercises within the college, which students had at their disposal, body weight in students during the first year of studies increased by $1.28 \mathrm{~kg}$, fat percentage in the body by $0.20 \%$ increased, BMI increased by $0.47 \mathrm{~kg}$ - $\mathrm{m}^{-2}$, and also body fat mass increased by $0.43 \mathrm{~kg}$ (Hoffman et al., 2006). The second study found that besides increasing all morphological status variables during the first year of the study, during the summer break, the trend continuously increased in the observed morphological variables, where the body weight increased by $1.3 \mathrm{~kg}$ during the school year increased by $0.1 \mathrm{~kg}$ and through the discharge, while the percentage of fat that increased during the school year by $0.9 \%$ increased further by $1.7 \%$ and over the holiday, while BMI increased by $0.8 \mathrm{~kg} \cdot \mathrm{m}^{-2}$ during the summer break (Hull et al., 2007).

It was found that the body structure in students statistically significantly correlates with the degree of physical activity, that is, with the level of metabolic consumption expressed in MET ( $\left.\mathrm{hrs} \cdot \mathrm{wk}^{-1}\right)$, and that exactly the level of physical activity inverted correlates with the percentage of fat in the body $(r=$ $-0.40)$, that is, the amount of total fat in the organism $(r=-0.26)$ (Zanovec et al., 2009). Also, changes in the body structure towards an increase in BMI, increase in the percentage of body fat, or a reduction in the mass of the contractile component (proteins and skeletal muscles) adversely affect the state of general and specific physical abilities, and changes in weight gain and percentage of fat with a decrease in aerobic endurance, as a negative adaptation to the sedentary lifestyle, is much more apparent in the initiation of 
more leaner students than in those who have already come to study with superfluous body status (Meckel et al., 2011).

Compared to the sample of students of the Criminal Police Academy in Belgrade, where the prevalence of obesity was only $12.50 \%$ (compared to Proc_BF more than 30.0\%), in our examined sample, the same prevalence was $29.60 \%$, which is 2.37 times more and is much more similar to the prevalence of the student population in America (from 20\%, Hull et al., 2007), that is, the student population in Israel (from 29.9\%, Meckel et al., 2011).

At the beginning of the third millennium a new phenomenon was observed, and especially in the young female population - a tendency towards a "skinny" look (Cheney, 2011), where the phenomenon of new body status emerged due to various habitual, nutritional and social factors. Namely, the methodological approach of crossing two criteria of obesity (BMI and\% $\mathrm{BF}$ ) revealed the profile of the new subclass of morphological status (Romero-Corall et al., 2008), which is: skinny or and lean fat, are skinny or have normal (lean) BMI values, but at the same time a high level of fat percentage in the body. The latest research on the general student population of the Belgrade University has shown that the prevalence in relation to the category of malnourished-fat is at the level of $1.07 \%$, while compared to the category normal-fat at the level of 6.59\% (Dopsaj, 2018). Compared to the data from the current study, the prevalence among FASPERA students is for underweight-fat at the level of $1.6 \%$, while for the category it is normal-fat at the level of $10.4 \%$. In other words, the overall prevalence for the category of lean-fat person was at the level of $12.0 \%$ (14 out of 125).

Generally speaking, the body structure of the FASPERA female students, where there is a suffusion of the fat tissue component of $3.20 \mathrm{~kg}$, with a deficit of $3.36 \mathrm{~kg}$ of the contractile component (Table 1 ), only indicates the apparent qualitative and quantitative imbalance of the diet, towards increased energy intake, from the category of "fast food" or "sweet food" and reduced energy consumption, especially in the shortage of systematic exercise, which consequently increases fat metabolism and protein synthesis, exercise with some of the types of extra load (fitness or gym). It was found that even a very small positive daily energy balance of only 2-3\% (about $112 \mathrm{Kcal} /$ day) resulted in an increase in the total TM of female students per semester of about $1.4 \mathrm{~kg}$, or about $0.70 \%$ of body weight, of which the fat component increases by $1.9 \mathrm{~kg}$, or by $2.60 \%$ (Hull et al., 2007).

Unfortunately, based on the results of this study, it can be generally concluded that the morphological status of FASPERA students from the tested sample at the level of persons with normal BMI (generally normal weight), but with an increased percentage of fat tissue and a decreased percentage of muscle tissue. This profile of the body structure does not represent an adequate values of nutrition as an acceptable initial morphological basis that preserves the organometabolic status of young female persons needed for all professional and life requirements in the future.

\section{CONCLUSION}

Based on BMI distribution, it can be claimed that $77.60 \%$ of subjects are of normal nutritional status, but also that the overall prevalence of subjects with overweight (BMI <25.00) and obese at the level of $11.20 \%$, or only the prevalence of obesity (BMI $<30.00$ ) are at the level of $4.00 \%$. Also, the prevalence of insufficient nutrition (BMI> 18.50) was found to be $11.20 \%$, with as many as $4.00 \%$ of subjects and significantly malnourished (BMI> 17.50).

It was found that as many as $96.8 \%$ of subjects responded to the ideal nutrition profile. In relation to the deviation of the deficit, $63.2 \%$ of respondents have some form of deficiency in body weight (a 5.25 $\mathrm{kg}$ body weight deficit), with the highest deficiency of the muscular component of $78.4 \%$ (muscle mass deficit of $4.28 \mathrm{~kg}$ ) compared to the deficit mass components $43.2 \%$ (average weight deficit of 2.01 $\mathrm{kg}$ ). There are $33.6 \%$ with the profile of some surplus, of subjects (an average surplus of body weight of $9.44 \mathrm{~kg}$ ), where as much as $54.4 \%$ has a surplus fat component (at an average level of a weight of 7.48 $\mathrm{kg}$ ). Unfortunately, only $3.2 \%$ of respondents had an optimal body structure in all observed structural segments.

The results of the $4 \mathrm{D}$ model of the body structure of FASPERA students can be defined as follows: 31.75 L of water (53.37\%), $8.50 \mathrm{~kg}$ of protein (14.26\%), 16.98 $\mathrm{kg}$ of fat $(27.10 \%)$ and $3.10 \mathrm{~kg}$ of minerals $(5.18 \%$ of TM).

In addition to the existing probability is that FASPERA students, the nutrition is the reason for 
the increased fat components, and the fact that even $69.6 \%$ of them are not physically active at all, or $21.6 \%$ at times, that is $91.2 \%$ are not adequately physically active, indicates a possible reason why a deficiency of the fat component, on the one hand, or a deficiency of the muscular component, on the other side.

Unfortunately, based on the obtained results of this study, it can be generally concluded that the morphological status of the FASPERA students studied is at the level of persons with normal BMI (generally normal weight), but with fatty tissue suffusion and muscle tissue deficit. This profile of the body structure does not represent an adequate nutritional value as an acceptable initial morphological basis that provides

\section{REFERENCE}

1. Dopsaj, M. (2018). Body composition characteristics of the Belgrade university students defined by the multichanal bioimpedance method. In: Stanković V., Stojanović, T. (Ed), The $5^{\text {th }}$ International Scientific Conference "Anthropological and Teo-Anthropological views on Physical Activity from the time of Constantine the Great to modern times", Kopaonik, 21.-24. mart 2018, Book of Abstracts (pp. 22-23), Univerzitet u Prištini, Leposavić: Fakultet sporta i fizičkog vaspitanja.

2. Dopsaj, M., Markovic, M., Kasum, G., Jovanovic, S., Koropanovski, N., Vukovic, M. \& Mudric, M. (2017). Discrimination of different body structure indexes of elite athletes in combat sports measured by multi frequency bioimpedance method. International Journal of Morphology, 35(1), 199-207.

3. Dopsaj, M., Ilić, V., Đorđević-Nikić, M., Vuković, M., Eminović, F., Macura, M., \& Ilić D. (2015). Descriptive model and gender dimorphism of body structure of physically active students of Belgrade University: Pilot study. Anthropologist, 19(1), 239-248.

4. Dopsaj, M., Todorov, I., Vuković, M., \& Radovanović, D. (2013). Various morphological indicators in elite judo athletes defined by multifrequency bioelectrical impedance analysis. Serbian Journal of Sports Sciences, 7(3), 129-141. the organo-metabolic status of young female persons needed for all professional and life requirements in the future.

\section{Acknowledgment}

This paper is a part of the Project "Effects of applied physical activity on the locomotor, metabolic, psycho-social and educational status of the population of the Republic of Serbia" under the number III47015, and a part of the subproject "Effects of Applied Physical Activity on the Locomotor Metabolic Psychosocial and Educational Status of the Population of the Students of the R Serbia" which is financed by the Ministry of Education and Science of the Republic of Serbia - the Scientific Projects Cycle 2011-2019.

5. Dopsaj, M., Dimitrijević, R. (2013). Klasifikacija studentkinja Kriminalističko-policijske akademije u odnosu na telesni sastav meren metodom multikanalne bioelektrične impedance. [Classification of students of the Criminal Police Academy in relation to the body composition measured by the method of multichannel bioelectric impedance, In Serbian]. Nauka, Bezbednost, Policija - Žurnal za kriminalistiku i pravo, 18(1), 39-56.

6. Dopsaj M, Blagojević M, Marinković B, Miljuš D, Vučković G, Koropanovski N, Ivanović J, Atanasov D, i Janković R. (2010). Modelne karakteristike osnovnih antropometrijskih pokazatelja i bazično-motoričkih sposobnosti (BMS) zdravih i utreniranih mladih osoba oba pola - populacioni pokazatelji Republike Srbije. [Model characteristics of basic anthropometric indicators and basic-motor abilities (BMS) of healthy and motivated young people of both sexes - population indicators of the Republic of Serbia, In Serbian]. Kriminalističko-policijska akademija: Beograd.

7. Đorđević-Nikić, M., Dopsaj, M., Rakić, S., Subošić, D., Prebeg, G., Macura, M., Mlađan, D., i Kekić, D. (2013). Morfološki model populacije radno aktivnih žena Beograda meren metodom električne multikanalne bioimpedance: Pilot istraživanje. [Morphological model of the population of working women of Belgrade measured by the method of electrical multichannel bioimpedance: Pilot research, In Serbian]. Fizička Kultura-Beograd, 67(2), 103-112. 
8. Zanovec, M., Lakkakula, A., \& Johnson, G.T. (2009). Physical activity is associated with percent body fat and body composition but not bady mass index in white and black college students. International Journal of Exercise and Science, 2(3), 175-185.

9. InBody 720 (2005). The precision body composition analyzer: User's Manual, 1996-2005 Biospace Co., Ltd., Korea: Gangam-gu, Seoul.

10. Jorga, J., Maksimović, M., i Davidović, D. (2007). Konvencionalno lečenje gojaznosti.[Conventional treatment of obesity. In Serbian]. Acta Clinica, 7(2), 79-94.

11. Kyle, U.G., Melzer, K., Kayser, B., Gremon, G., \& Pichard, C. (2006). Eight year longitudinal changes in body composition in healty Swiss adults. Journal of American College of Nutrition, 25(6), 493-501.

12. Kyle, U.G., Schutz, Y., Dupertuis, Y., \& Pichard, C. (2003). Body composition interpretation: Contribution of the fat-free mass index and the body fat mass index. Nutrition, 19, 597-604.

13. Mott, J.W., Wang, J., Thornton, J.C., Allison, D.B., \& Heymsfield, SB (1999). Relation between body fat and age in 4 ethnic groups. American Journal of Clinical Nutrition, 69(5). 1007-1013.

14. Meckel, Y., Galily, Y., Nemet, D., \& Eliakim, A. (2011). Changes in weight indexes and aerobic fitness of physical education students over three years of college. Journal of Human Sports Exercises, 6(1).112-121.

15. Pavlica, T., Božić-Krstić, V., \& Rakić, R. (2008). Body height and weight in adult population in Srem, Banat and Bačka (Vojvodina). Glasnik Antropološkog društva Srbije, 43, 329-335.

16. Romero-Corral. A,, Lopez-Jimenez, F., SierraJohnson, J., \& Somers, V.K. (2008). Differentiating between body fat and lean mass-how should we measure obesity? Nature Clinical Practice. Endocrinology \& Metabolism, 4(6), 322-3.
17. Rothman, K.J. (2008). BMI - related errors in the measurement of obesity. International Journal of Obesity, 32, S56-S59.

18. Stommel, M., \& Schoenborn, C. (2010). Variations in BMI and prevalence of health risk in diverse racial and ethnic population. Obesity, 18, 1821-1826.

19. Hair, J., Anderson, R., Tatham, R., \& Black, W. (1998). Multivariate data analysis ( ${ }^{\text {th }}$ Ed.). New Jersey, USA: Prentice-Hall. Inc.

20. Hajnalka, P., i Čaba, P. (2017). Veza između stila života i statusa uhrnjenosti u populaciji adolescenata. [Relationship between lifestyle and obesity status in adolescent populations. In Serbian]. Fizička Kultura- 71(2), 145-153.

21. Heyward, V., \& Stolarczyk, L. (1996). Applied Body Composition Assessment. Champaign, IL: Human Kinetics.

22. Hull, H., Morrow, M., Heesch, K., Dinger, M., Han, J., \& Fields, D. (2007). Effects of the summer months on body weight and composition in college woman. Journals of Women's Health, 16(10), 1501-1515.

23. Hoffman, D., Policastro, P., Quick, V., \& Lee, S-K. (2006). Changes in body weight and fat mass of man and woman in the first year of college: A study of the "Freshman 15". Journal of American College Health, 55(1), 41-45.

24. Casey, V., Dwyer, J., Coleman, A., \& Valadian, I. (1992). Body mass index from childhood to middle age: a 50-y follow-up. American Journal of Clinical Nutrition, 56, 14-18.

25. Cheney, M.A. (2011). "Most girls want to be Skinny": Body (Dis)Satisfaction among ethnically diverse women. Qualitative Health Research, 21(10), 1347-1359.

26. World Health Organisation (2000). Obesity: Preventing and managing the global epidemic. Geneva: WHO Technical Report Series 894.

Submitted: 04.02.2018.

Accepted: 07.11.2018.

Published Online First: 30.06.2019. 


\title{
МОДЕЛНЕ КАРАКТЕРИСТИКЕ ТЕЛЕСНЕ СТРУКТУРЕ СТУДЕНТКИЊА ФАКУЛТЕТА ЗА СПЕЦИЈАЛНУ ЕДУКАЦИЈУ И РЕХЕБИЛИТАЦИЈУ (ФАСПЕР) ИЗМЕРЕНЕ МЕТОДОМ МУЛТИКАНАЛНЕ БИОЕЛЕКТРИЧНЕ ИМПЕДАНЦЕ
}

\author{
Миливој Допсај ${ }^{1,4}$, Фадиљ Еминовић ${ }^{2}$, Марина Ђорђевић-Никић ${ }^{1}$, Драган Миљуш ${ }^{3}$, Горан Касум ${ }^{1}$ \\ ${ }^{1}$ Факултет спорта и физичког васпитања, Универзитет у Београду, Србија \\ ${ }^{2}$ Факултет за специјалну едукацију и рехебилитацију, Универзитет у Београду, Србија \\ ${ }^{3}$ Институт за јавно здравље Републике Србије „Др Милан Јовановић Батут“, Београд, Србија \\ ${ }^{4}$ Инситут спорта, туризма и услуга, Јужно-уралски Универзитет, Чељабинск, Русија
}

\begin{abstract}
Сажетак
Циљ истраживања је дефинисање моделских карактеристика телесне структуре студенткиња ФАСПЕРА Универзитета у Београду, као особа чије је будуће радно опредељење рад са инвалидним лицима, што представља веома одговоран, стресан и атипичан професионални радни профил. Узорак је био састављен од 125 испитаница. Мерења су извршена у Методичко-истраживачкој лабораторији Факултета спорта и физичког васпитања Универзитета у Београду, помоћу анализатора телесне структуре - InBody 720. Истраживањем је обухваћено двадесет (20) варијабли. Резултати су показали да је 77.60 \% испитаница у статусу нормалне ухрањености, да је преваленција испитаница са прекомерном тежином (БМИ <25.00) 7.20\%, односно гојазности (БМИ <30.00) 4.00\%. Такође, утврђено је и да је преваленција недовољне ухрањености (БМИ > 18.50) 11.20\%, где је чак 4.00\% испитаница и значајно неухрањено (БМИ >17.50). Резултати су показали да чак 96.8 \% испитаница одсупа од профила идеалне ухрањености. У односу на одступање ка дефициту, 63.2\% испитаница има неки облик дефицита телесне масе (просек дефицита телесне масе од 5.20 кг) и то их има највише са дефицитом мишићне компоненте 78.4\% (дефицит од 4.28 кг), као и у односу на дефицит масне компоненте 43.2\% (дефицит од 2.01 кг). Са профилом неког од суфицита има 33.6\% испитаница (суфицит телесне масе од 9.44 кг), где чак 54.4\% има суфицит масне компоненте (суфицит од 7.48 кг). Поред вероватноће да је начин исхране разлог за повећане масне компоненте, и чињеница да чак $69.6 \%$ није, а $21.6 \%$ само повремено, односно укупно $91.2 \%$ испитаница није адекватно физички активно, указује на могући разлог зашто је код њих утврђен суфицит масне, односно дефицит мишићне компоненте.
\end{abstract}

Кључне речи: ПРОЦЕНАТ МАСТИ/ ПРОЦЕНАТ МИШИЋА/ СТУДЕНТКИҢЕ/ ТЕЛЕСНИ САСТАВ/ УНИВЕРЗИТЕТ У БЕОГРАДУ

\section{УВОД}

Поред основних морфолошких карактеристика, телесне висине (ТВ) и телесне масе (ТМ), тело човека има и своју структуру. Термином телесна структура дефинише се састав и међусобни однос свих органских ткива, као биолошки скуп материја, од којих се састоји људски организам (Heyward \& Stolarczyk, 1996).

На макро нивоу, људски организам се састоји од четири основна елемента (сегмента), као глав- них биолошких мерљивих материја и то: вода, масна, протеинска и минерална компонента. Математички посматрано, односи ових основних елемената дефинишу морфолошке индексе, на основу којих се израчунава заступљеност појединих елемената у телу, а чиме се утврђују пропорције, односно телесна структура (Heyward and Stolarczyk, 1996; Dopsaj et al., 2013; Dopsaj et al., 
2015). Дати елементи имају пресудан значај за клиничку праксу и дефинисање стања ухрањености појединаца, али и представљају променљиве, тј. варијабле од интереса за научна истраживања у примењеној антропологији (педагошка, медицинска, културолошка, еволутивна итд.) (Mott et al., 1999; WHO, 2000; Kyle et al., 2006; Stommel and Schoenborn, 2010).

Студенти представљају популацију особа од највећег интереса за неко друштво, јер су они носиоци развоја тог истог друштва у непосредној, ближој и даљој будућности. То се нарочито односи на студенткиње Факултета за специјалну едукацију и рехабилитацију (ФАСПЕР) јер се оне школују за стручњаке високог профила које ће се током радног века професионално бавити особама са одређеним степеном и врстом инвалидитета. Другим речима, професионални радни профил ће имати карактеристике посла у смислу перманентне изложености стресним ситуацијама у односу на активности и специфичне видове рада и третмана са особама са поремећајима у говору, језику и комуникацији, поремећаја вида, слуха, социјалног понашања, као и различитих психолошких, физичких и мишићно-неуралних дефицита. Перманентна изложеност оваквим професионално радним агенсима, повећава и ризик за прекомерни негативни кумулативни утицај у смислу здравственог, физичког, односно телесног статуса за будућност.

Праћење навика у физичкој активности, навика у исхрани, али и стања и промена телесног статуса још од школских дана, па и у студентском периоду, је веома важан поступак јер обезбеђује иницијалне информације о истраживаном простору, односно утврђује чињенице о актуелном морфолошком статусу са почетка периода образовања, односно периода одрастања (Hoffman et al., 2006; Dopsaj i sar., 2010; Meckel et al., 2011; Hajnalka i Čaba, 2017). Поред личних друштвеносоцијалних и професионалних промена које у блиској будућности очекују популацију студената, постоје и неизбежни биолошки утицаји који се дешавају током одрастања и старења, а које модерно доба и урбанизација доноси као промена стила живота савременог човека. Два основна фактора модерног начина живота су редукована физичка активност и повећани енергетски уноси, условили су феномен који се манифестује кроз енормно увећање преваленце гојазних особа, од- носно особа са увећаним процентом масног ткива у организму. Поменути феномен је постао главна одредница повећања заступљености незаразних болести код човека модерног доба (WHO, 2000).

Досадашњи мерни поступци и процедуре у области истраживања телесног састава, као и степена ухрањености и морфолошких карактеристика код људи се претежно базира на израчунавању индекса телесне масе (БМИ - Body Mass Index), односно мерењу кожних набора и/или обима различитих екстремитета тела, и употреби датих података у смислу њиховог прерачунавања за потребе процене одређених структурних елемената, применом математичких формула (Heyward and Stolarczyk, 1996). Међутим, утврђено је да таква врста процењивања има и великих грешака предикције, док се за БМИ све више потврђује да у одеђеним вредносним зонама није довољно специфичан и сензитиван у функцији предикције стварних вредности телесног састава, а нарочито у односу на ниво масти у организму (Kyle et al., 2003; Rothma, 2008).

Мерни инструменти најновије генерације који користе нову технологију мерења телесне структуре користе принцип мултиканалне електричне биоимпеданце и са великом поузданошћу и тачности мерења обезбеђују валидне научне податке о садржају и структури тела (InBody 720, 2005; Dopsaj et al., 2017).

Циљ овог истраживања је дефинисање карактеристика модела телесне структуре студенткиња ФАСПЕРА Универзитета у Београду. Аналитички и дијагностички аспект добијених резултата ће указати на актуелни ниво квантитативних карактеристика посматраног телесног простора код будућих професионалаца у раду са инвалидним лицима, односно као носиоцима посла, женског пола, у раду са инвалидним лицима. Такође, добијени резултати ће указати и на актуелни профил телесне структуре младих девојака академског усмерења, као дела београдске универзитетске популације, опредељених ка друштвено-хуманистичком профилу образовања.

\section{МЕТОД РАДА}

Ово истраживање је неекспирименталног карактера, док у односу на тип припада дескриптивно-анамнестичкој студији. 


\section{Узорак испитаника}

Узорак је састављен од 125 студенткиња III и IV године основних дипломских студија ФАСПЕР-а Универзитета у Београду. Основни дескриптивни подаци о испитаницама су били: узраст $=22.5 \pm 1.9$ година, ТВ $=166.7 \pm 6.5$ цм, ТМ $=60.3 \pm 12.1$ кг. У односу на учесталост физичке активности (ходање) или физичко вежбање (спортски тренинг, организована, самостална рекреација или фитнес) 87 испитаница (69.6\%) уопште није било физички активно или није вежбало, односно имало је седентаран начин живота, 27 испитаница (21.6\%) је било повремено физички активно или је повремено вежбало (2-3 пута недељно), 7 испитаница (5.6\%) је било редовно физички активно или је вежбало (4-5 пута недељно), а само 4 испитанице (3.2\%) је било интензивно физички активно, тј. интензивно је вежбало (више од 6 пута недељно). $\mathrm{y}$ односу на испитанице које су биле физички активне или су вежбале, просечна појединачна

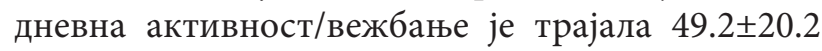
минута, односно сумарно на недељном нивоу, дата активност/вежбање је трајало $147.3 \pm 126.6$ минута.

\section{Мерење телесне структуре}

Сва мерења су извршена у Методичко-истраживачкој лабораторији (МИЛ) Факултета спорта и физичког васпитања Универзитета у Београду у периоду од 2012-2017 године, у јутарњим часовима између 09:00 и 11:00. Мерења су спроведена у складу са стандардизованом процедуром (најмање 24 часа пре мерења била је забрањена конзумација алкохола и примена физичког вежбања, најмање 2 сата пре мерења било је забрањено узимати храну и воду, најмање 5 минута пре мерења све испитанице су стајале, а мерење је спроведено у лаганој спортској одећи, најмање 30 минута пре мерења испитанице су завршиле са физиолошким пражњењем, и током мерења нико није имао на себи ништа од метала) помоћу методе електричне мултиканалне биоимпеданце са анализатором телесне структуре најновије генерација - InBody 720 (InBody 720, 2005).

\section{Варијабле}

Овим истраживањем је обухваћено двадесет (20) варијабли и то осам (8) основних и дванаест (12) изведених, односно индексних варијабли, помоћу којих су дефинисане карактеристике модела телесне структуре испитаница.

Основне варијабле су биле следеће:

1. ТВ - телесна висина, изражена у цм,

2. ТМ - телесна маса, изражена у кг,

3. ФФМ - безмасна маса тела (Free Fat Mass), изражена у кг,

4. Протеини - маса протеина у телу, изражена укг,

5. Минерали - укупна маса минерала у телу, изражена у кг,

6. БФ - укупна маса масти у телу (Body Fat), изражена у кг,

7. СММ - маса скелетних мишића у телу (Skeletal Muscle Mass), изражена у кг,

8. ВФА - површина висцералних масти (Visceral Fat Area), изражена у цм².

Изведене (индексне) варијабле су биле следеће:

1. БМИ - индекс телесне мace (Body Mass Index), изражен у кг $\bullet \mathrm{M}^{-2}$,

2. Тарг_БМ - идеална телесна маса (Target BM), изражена у кг,

3. W_Контрол - препоручена корекција актуелне телесне масе (Weight Control), изражено у кг,

4. Ф_Контрол - препоручена корекција масе укупних масти (Fat Control), изражено у кг,

5. M_Контрол - препоручена корекција масе скелетних мишића (Muscle Control), изражено у кг,

6. Фитнесс_Ckop - квантитативна (нумеричка) оцена телесног статуса, изражена у бодовном скору,

7. ПБФ - проценат укупних масти у телу (Percent of Body Fat Mass), изражен у \%,

8. ПСММ - проценат скелетних мишића у телу (Percent of Skeletal Muscle Mass), изражен у \%,

9. ФМИ - индекс телесних масти (Fat Mass Index), изражен у кг $\bullet \mathrm{M}^{-2}$,

10. СММИ - индекс скелетних мишића (Skeletal Muscle Mass Index), изражен у кг $\bullet \mathrm{M}^{-2}$,

11. ФФМИ - индекс безмасне масе (Fat Free Mass Index), изражен у кг $\bullet \mathrm{M}^{-2}$,

12. ПФИ - протеинско масни индекс (Protein Fat Index), изражен у кг. 


\section{Статистичка обрада података}

Сви сирови резултати су убачени у стандардни софтверски програм EXCEL ради формирања базе података и вршења логичке провере резултата. Након логичке провере, применом процедура дескриптивне статистике, израчунати су потребни параметри централне тенденције и дисперзије података (Mean, SD, cV\%, Std. Error, Skewness, Kurtosis, Min, Max и интервал поузданости на 95\%). Правилност дистрибуције варијабли је проверавана применом непараметријског теста Колмогоров-Смирнов (КСЗ), док су моделске вредности дистрибуције дефинисане помоћу перцентила. За све статистичке процедуре коришћен је софтверски пакет SPSS Statistics 17.0 (Hair et al., 1998).

\section{РЕЗУЛТАТИ}

Основни дескриптивни статистици испитиваних варијабли телесне структуре су приказани у Табели 1. У Табели 2 су дати резултати перцентилне дистрибуције свих испитиваних варијабли дефинисаних у односу на девет карактеристичних класа резултата $(2.5,5.0,10.0,25.0,50.0,75.0,90.0$, 95.0 и 97.5 перцентил).

Табела 1 Основни дескриптивни статистици испитиваних варијабли

\begin{tabular}{|c|c|c|c|c|c|c|c|c|c|c|}
\hline \multirow{2}{*}{ Varijabla } & \multirow{2}{*}{ Mean } & \multirow{2}{*}{ SD } & \multirow{2}{*}{ cV\% } & \multirow{2}{*}{$\begin{array}{l}\text { Std. } \\
\text { Error }\end{array}$} & \multirow{2}{*}{ Skew } & \multirow{2}{*}{ Kurt } & \multirow{2}{*}{ Min } & \multirow{2}{*}{ Max } & \multicolumn{2}{|c|}{$\begin{array}{l}\text { 95\% Conf. } \\
\text { Interval }\end{array}$} \\
\hline & & & & & & & & & $\begin{array}{l}\text { Lower } \\
\text { Bound }\end{array}$ & $\begin{array}{l}\text { Upper } \\
\text { Bound }\end{array}$ \\
\hline $\mathrm{TV}(\mathrm{cm})$ & 166.7 & 6.5 & 3.9 & 0.58 & 0.24 & -0.01 & 151.7 & 185.7 & 165.5 & 167.8 \\
\hline TM (kg) & 60.31 & 12.11 & 20.1 & 1.1 & 2.17 & 6.73 & 44.4 & 114.7 & 57.2 & 62.5 \\
\hline BMI $\left(\mathrm{kg} \cdot \mathrm{m}^{-2}\right)$ & 21.67 & 3.87 & 17.9 & 0.35 & 2.19 & 6.44 & 16.19 & 39.18 & 20.99 & 22.36 \\
\hline FFM (kg) & 43.24 & 5.13 & 11.9 & 0.46 & 0.84 & 1.85 & 33.20 & 61.94 & 42.34 & 44.15 \\
\hline Proteini (kg) & 8.47 & 0.98 & 11.6 & 0.09 & 0.68 & 1.16 & 6.60 & 11.80 & 8.29 & 8.64 \\
\hline Minerali (kg) & 3.08 & 0.41 & 13.3 & 0.04 & 1.05 & 2.62 & 2.20 & 4.64 & 3.01 & 3.15 \\
\hline $\mathrm{BF}(\mathrm{kg})$ & 17.00 & 8.27 & 48.7 & 0.74 & 2.46 & 7.48 & 7.40 & 53.70 & 15.53 & 18.46 \\
\hline SMM (kg) & 23.54 & 2.98 & 12.7 & 0.27 & 0.69 & 1.19 & 18.00 & 33.70 & 23.02 & 24.07 \\
\hline VFA $\left(\mathrm{cm}^{2}\right)$ & 47.75 & 29.31 & 61.4 & 2.62 & 1.93 & 4.64 & 9.50 & 168.0 & 42.56 & 52.94 \\
\hline Targ_TM (kg) & 60.47 & 5.38 & 8.9 & 0.48 & 0.90 & 2.14 & 49.50 & 80.50 & 59.52 & 61.43 \\
\hline W_control (kg) & 0.16 & 9.26 & 5787 & 0.83 & -1.77 & 4.31 & -38.70 & 14.60 & -1.48 & 1.80 \\
\hline F_control (kg) & -3.20 & 7.73 & 241.6 & 0.69 & -2.27 & 6.44 & -38.70 & 6.00 & -4.57 & -1.83 \\
\hline M_control (kg) & 3.36 & 2.87 & 85.4 & 0.26 & 0.60 & -0.18 & 0.00 & 13.00 & 2.85 & 3.87 \\
\hline Fitness_Score (bod) & 72.24 & 5.63 & 7.8 & 0.50 & -1.10 & 2.36 & 48.00 & 83.00 & 71.24 & 73.24 \\
\hline Proc_BF (\%) & 26.14 & 6.87 & 26.3 & 0.61 & 1.10 & 0.92 & 16.48 & 51.59 & 25.92 & 28.36 \\
\hline Proc_SMM (\%) & 39.57 & 3.70 & 9.4 & 0.33 & -0.99 & 0.62 & 26.90 & 45.43 & 38.91 & 40.22 \\
\hline FMI $\left(\mathrm{kg} \bullet \mathrm{m}^{-2}\right)$ & 6.11 & 2.87 & 47.0 & 0.27 & 2.34 & 6.98 & 2.74 & 20.21 & 5.60 & 6.61 \\
\hline SMMI $\left(\mathrm{kg} \bullet \mathrm{m}^{-2}\right)$ & 8.46 & 0.82 & 9.7 & 0.07 & 0.56 & 0.65 & 6.71 & 11.00 & 8.32 & 8.61 \\
\hline FFMI $\left(\mathrm{kg} \mathrm{m}^{-2}\right)$ & 15.55 & 1.36 & 8.8 & 0.12 & 0.67 & 1.25 & 12.63 & 20.23 & 15.30 & 15.79 \\
\hline PFI (kg) & 0.567 & 0.168 & 29.6 & 0.015 & -0.07 & -0.39 & 0.184 & 1.000 & 0.536 & 0.596 \\
\hline
\end{tabular}


На основу резултата приказаних у Табели 1, може се тврдити да је вредност коефицијената варијације (cV\%), код следећих варијабли, изнад граничних за хомогени скуп и то: укупна маса телесних масти, БФ - 48.7\%, површина висцералних масти, ВФА - 61.4\%, препоручена редукција актуелне телесне масе, W_kонтрол - 5787.0\%, препоручена редукција масне компоненте телесне масе, Ф_контрол - $241.6 \%$, препоручена редукција мишићне компоненте телесне масе, M_kонтрол - 85.4\%, и индекс телесних масти, ФМИ - 47.0\%. Преосталих четрнаест варијабли имају карактеристике хомогеног скупа, јер им се вредности коефицијента варијације налазе испод граничне вредности, односно мањи су од $30.0 \%$.
Наосновумераспљоштеностии закривљености дистрибуције резултата може се тврдити да код седам варијабли постоји наглашена платикуртичност дистрибуције истих (ТМ, БМИ, БФ, ВФА, W_kонтрол, Ф_kонтрол и ФМИ), односно измерени испитаници су мање дистрибуирани у зони просечних, већ је облик дистрибуције асиметрично резвучен ка већим вредностима варијабли. То истовремено значи, да је код свих поменутих варијабли, већина измерених вредности испитаница концентрисана на нижим вредностима истих.

Табела 2 Резултати перцентилне дистрибуције свих испитиваних варијабли

\begin{tabular}{|c|c|c|c|c|c|c|c|c|c|}
\hline \multirow{2}{*}{ Varijable } & \multicolumn{9}{|c|}{ Percentili (\%o) } \\
\hline & 2.5 & 5 & 10 & 25 & 50 & 75 & 90 & 95 & 97.5 \\
\hline $\mathrm{TV}(\mathrm{cm})$ & 153.7 & 155.7 & 159.0 & 162.0 & 166.1 & 170.5 & 175.6 & 177.3 & 181.3 \\
\hline TM (kg) & 44.6 & 45.6 & 48.6 & 53.6 & 58.0 & 64.1 & 73.6 & 83.6 & 102.8 \\
\hline BMI $\left(\mathrm{kg} \bullet \mathrm{m}^{-2}\right)$ & 16.66 & 17.57 & 18.21 & 19.43 & 20.84 & 22.49 & 27.20 & 29.59 & 36.45 \\
\hline FFM (kg) & 34.66 & 35.76 & 36.84 & 39.37 & 43.11 & 46.30 & 49.43 & 51.24 & 57.45 \\
\hline Proteini (kg) & 6.80 & 7.00 & 7.20 & 7.70 & 8.50 & 9.00 & 9.70 & 9.97 & 11.18 \\
\hline Minerali (kg) & 2.42 & 2.52 & 2.55 & 2.80 & 3.02 & 3.26 & 3.49 & 3.79 & 4.26 \\
\hline BF (kg) & 7.71 & 9.63 & 10.80 & 12.00 & 14.30 & 19.35 & 27.78 & 31.88 & 50.64 \\
\hline SMM (kg) & 18.42 & 19.03 & 19.76 & 21.25 & 23.70 & 25.30 & 27.14 & 28.07 & 31.73 \\
\hline VFA $\left(\mathrm{cm}^{2}\right)$ & 11.59 & 15.04 & 19.36 & 29.80 & 40.90 & 58.65 & 82.28 & 108.31 & 155.09 \\
\hline Targ_TM (kg) & 50.8 & 52.2 & 54.3 & 56.8 & 60.2 & 63.3 & 66.8 & 69.8 & 74.9 \\
\hline W_control $(\mathrm{kg})$ & -32.7 & -17.6 & -13.4 & -2.6 & 2.0 & 5.7 & 8.7 & 11.4 & 13.0 \\
\hline F_control (kg) & -32.7 & -17.6 & -13.7 & -6.2 & -0.4 & 1.3 & 3.1 & 4.0 & 5.0 \\
\hline M_control (kg) & 0.0 & 0.0 & 0.0 & 0.8 & 3.3 & 5.1 & 7.5 & 8.3 & 8.7 \\
\hline Fitness_Score (bod) & 57.0 & 62.0 & 66.0 & 69.0 & 73.0 & 76.0 & 78.0 & 79.0 & 81.7 \\
\hline Proc_BF (\%) & 17.2 & 19.7 & 20.4 & 22.1 & 25.0 & 31.3 & 37.4 & 40.6 & 45.8 \\
\hline Proc_SMM (\%) & 29.6 & 32.4 & 34.4 & 37.1 & 40.7 & 42.4 & 43.3 & 43.8 & 44.8 \\
\hline FMI $\left(\mathbf{k g} \bullet \mathbf{m}^{-2}\right)$ & 3.00 & 3.61 & 3.83 & 4.38 & 5.09 & 7.12 & 10.03 & 11.89 & 16.68 \\
\hline SMMI $\left(\mathbf{k g} \cdot \mathbf{m}^{-2}\right)$ & 7.13 & 7.22 & 7.38 & 7.96 & 8.37 & 8.88 & 9.53 & 9.88 & 10.53 \\
\hline FFMI $\left(\mathbf{k g} \cdot \mathbf{m}^{-2}\right)$ & 13.31 & 13.53 & 13.76 & 14.74 & 15.34 & 16.28 & 17.22 & 17.75 & 18.92 \\
\hline PFI (kg) & 0.23 & 0.29 & 0.33 & 0.43 & 0.59 & 0.69 & 0.77 & 0.80 & 0.94 \\
\hline
\end{tabular}


На Графикону 1 су приказане дистрибуције испитаница у односу на варијабле које дефинишу општи статус ухрањености (БМИ).

На основу дистрибуције БМИ може се тврдити да је $77.60 \%$ испитаница у статусу нормалне ухрањености (Табела 1, сумарни БМИ од 18.50 до 24.99), али и да је преваленција испитаница са прекомерном тежином (БМИ $=25.00$ до 29.99) $7.20 \%$, односно преваленција гојазности (БМИ $<30.00) 4.00 \%$. Такође, утврђено је и да је укуп- на преваленца недовољне ухрањености (БМИ $\geq 18.49) 11.20 \%$, где је чак $4.00 \%$ испитаница и значајно неухрањено (БМИ $\geq 17.49$ ).

На Графикону 2 су приказани резултати преваленце испитаница класификоване у односу на три категорије и то: испитанице са неким дефицитом или суфицитом морфолошке компоненте, односно испитанице са оптималним телесним статусом.

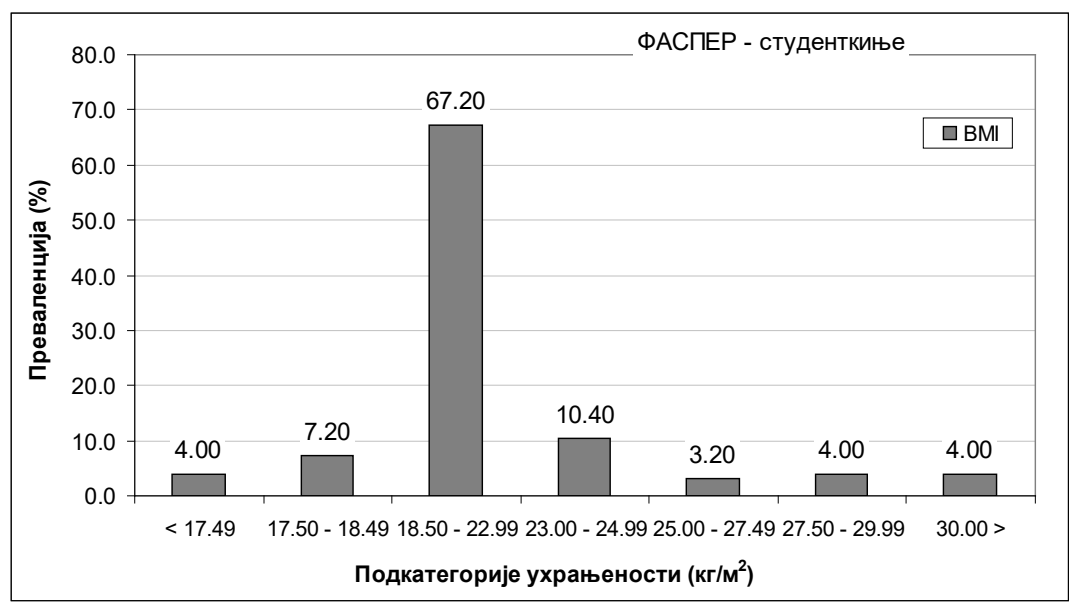

Графикон 1. Дистрибуција испитаница у односу на БМИ дефинисан у складу са WHO критеријумима (подкатегорије класа)

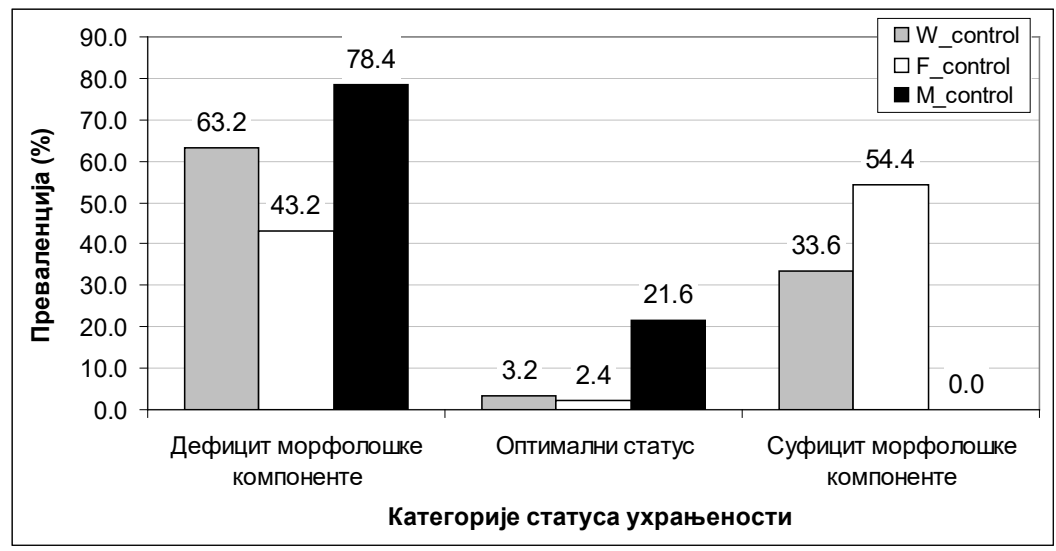

Графикон 2. Преваленца испитаница класификованих у односу на три категорије: испитанице са неким од дефицита или суфицита морфолошке компоненте и испитанице са оптималним телесним статусом

Резултати преваленце дефицита различитих морфолошких компоненти (Графикон 2) су показали да постоји већа учесталост дефицита, него што је учесталост суфицита, односно испитаница са оптималним телесним статусом. Генерално је утврђено да чак 63.2 \% испитаница има неки облик дефицита масе (W_kонтрол, просек дефицита телесне масе од 5.20 кг) и то највише са дефицитом мишићне компоненте 78.4\% (M_kонтрол, просек дефицита мишићне масе од 4.28 кг), односно дефи- 
цита масне компоненте $43.2 \%$ (Ф_kонтрол, просек дефицита масне масе од 2.01 кг). У односу на суфицит, 33.6\% испитаница има одређени суфицит ( $\mathrm{W}_{-}$ контрол, са просечним суфицитом телесне масе од 9.44 кг) где чак $54.4 \%$ има суфицит масне компоненте (Ф_kонтрол, на просечном нивоу суфицита масне масе од 7.48 кг). У целокупном истраживаном узорку, само $3.2 \%$ испитаница има оптималну телесну структуру, од чега само $2.4 \%$ у односу на масти, а $21.6 \%$ у односу на мишићну компоненту.

На Графикону 3 су приказани резултати дефинисаног 4Д модела телесне структуре студенткиња ФАСПЕРА измереног методом мултиканалне биоелектричне импеданце. Модел је представљен у апсолутним (кг) и релативним (\% од ТМ) вредностима.

Резултати 4Д модела телесне структуре испитиваних студенткиња се могу дефинисати на следећи начин: 31.75 Л воде (53.37\%), 8.50 кг протеина (14.26\%), 16.98 кг масти (27.10\%) и 3.10 кг минерала (5.18 \% од ТМ).
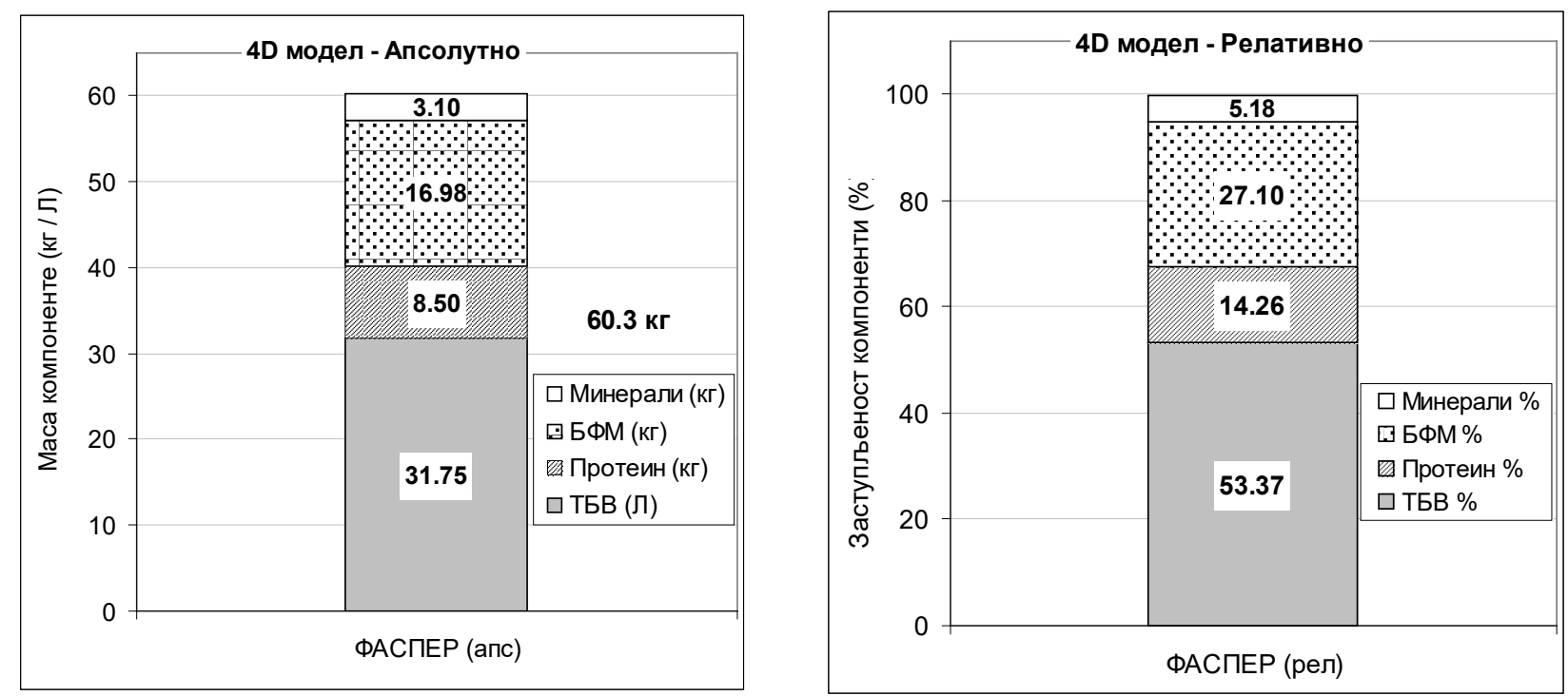

Графикон 3. Резултати дефинисаног 4Д модела (апсолутно, у кг, и релативно, у \% од ТМ) телесне структуре студенткиња ФАСПЕРА измереног методом мултиканалне биоимпеданце

\section{ДИСКУСИЈА}

Модерно друштво подразумева константан технолошки напредак, односно има сталну потребу за иновирањем свих потребних знања и сазнања, од којих зависи и социјално-друштвени напредак. Део дате технологије напретка може се препознати и у потреби сталног прикупљања информација о карактеристичним и битним деловима друштва, у којем квалитет живота, са свим својим позитивним и негативним странама чини важан сегмент (WHO, 2000). На тај начин се обезбеђује стална информациона база која чини основу за доношење одлука у смислу планирања, програмирања и корекције постојећег система организације друштва у складу са будућим и сав- ременим потребама (Dopsaj i sar., 2010).

Структура тела код људи, односно морфолошки простор, као појам, подразумева поље истраживања у науци која изучава облик и састав тела, и изучава основне димензије које дати облик и састав описуjу (Heyword and Stolarczyk, 1996). У односу на поменути биолошки систем и различите компоненте од којих је људско тело састављано, телесни статус тј. статус ухрањености је биолошки изузетно адаптабилна карактеристика и директно зависи од односа калоријског уноса и калоријске потрошње. Другим речима, телесни статус је директно подложан променама које зависе од начина исхране, начина живота и навика физичког вежбања, како у позитивном тако и у негативном смислу (WHO, 2000; Kyle et al., 2006; Hull et al., 2007). 
Са аспекта стандарда здравих и младих особа у Р Србији, може се тврдити, да се у односу на ТВ, испитивани узорак студенткиња ФАСПЕРА налази на двадесетом перцентилу, што значи да студенткиње припадају категорији испод просечно високих особа женског пола (Dopsaj i sar., 2010, стр. 202-204). У односу на ТМ и БМИ, испитивани узорак се са 60.31 кг и 21.67 кг $\bullet$ м-2 просечне вредности, налази у категорији просечне телесне масе и категорији просечног индекса телесне масе (Dopsaj i sar., 2010, стр. 205-207).

Према резултатима студије која је истраживала морфолошке карактеристика физички активних студената Београдског унивезитета са 12 факултета, где је у укупном узорку који је репрезентовао $0.30 \%$ популације било и 113 студенткиња (Dopsaj et al., 2015), утврђено је да је укупна преваленција прекомерно ухрањених и гојазних студенткиња, дефинисана преко БМИ, $10.30 \%$, док је код гојазности само $2.21 \%$. Такође, преваленција недовољне ухрањености је била $3.68 \%$. Упоређујући поменуте резултате може се тврдити да је укупна преваленција прекомерне ухрањености и гојазности код студенткиња ФАСПЕРА нешто виша него на Универзитету (11.20 вс $10.30 \%$, репсективно), али је преваленца гојазности скоро два пута већа (4.00 вс $2.21 \%$, респективно). Међутим, преваленца недовољно ухрањених студенткиња је код студенткиња ФАСПЕРА око 2.5 пута већа од студенткиња Београдског универзитета (11.20 вс $3.68 \%$, респективно). Другим речима, испитивани узорак студенткиња ФАСПЕРА, упоређујући их са физички активним студенткињама Београдског универзитета, показује карактеристике бимодалне ухрањености, односно тенденцију ка 2.5 пута већој преваленци мршавих и око 2 пута већој преваленци гојазних.

У односу на остале компоненте масног ткива, физички активне студенткиње Београдског универзитета имају за $14.71 \%$ мању укупну количину масног ткива (БФ), за $11.18 \%$ мању површину масти унутрашњих органа, односно висцералних масти (ВФА), као и за 9.83\% мањи проценат масног ткива него испитивани узорак студенткиња ФАСПЕРА. Овакви резултати указују на закључак да у односу на поменуте компоненте масти, испитиване студенткиње ФАСПЕРА, имају све показатеље масти, и апсолутне и релативне, за око 10 до 15\% веће, него физички активне студенткиње Београдског универзитета (Dopsaj et al., 2015). Поред постојеће вероватноће да је разлог за повећане масне депое код студенткиња ФАСПЕРА начин исхране, и чињеница да чак њих $69.6 \%$ уопште није, као и да је $21.6 \%$ само повремено, односно укупно $91.2 \%$ није адекватно физички активно, указује на разлог зашто је код њих утврђен суфицит масне компоненте (Табела 1).

Последично, а у односу на студенткиње БУ које су физички активне, код испитиваног узорка студенткиња ФАСПЕРА су потпуно обрнути резултати у односу на статус контрактилне компоненте. Наиме, оне си имале за 7.13\% мању масу протеина у телу (Протеин), и за чак $18.3 \%$ лошији индекс протеина и масти у телу (ПФИ) у односу на физички активне студенткиње Београдског универзитета (Dopsaj et al., 2015).

Ако се упореде релативне вредности телесне структуре 4Д модела дефинисаних на оба поменута узорка, стуенткиње ФАСПЕРА су имале за $3.8 \%$ мањи проценат укупне воде у телу (53.37 вс $55.48 \%$, респективно), имале су за $4.6 \%$ мањи проценат протеина, као контрактилне компоненте у телу (14.26 вс $14.94 \%$, респективно), имале су за $11.16 \%$ већи проценат масти у телу $(27.10$ вс $24.28 \%$, респективно) и имале су за $2.5 \%$ мањи проценат минерала у телу (5.18 вс 5.31\%) у односу на физички активне студенткиње Београдског универзитета (Dopsaj et al., 2015).

Оно што је веома карактеристично је то, да у односу на скоро истоветни ниво ухрањености између два анализирана узорка (актуелна студија БМИ $=21.67$, студенткиње Београдског универзитета 21.71 кг $\mathrm{M}^{-2}$ ), узорак испитиваних студенткиња ФАСПЕРА има обрнуто пропорционално различиту структуру тела, и то тако што постоји значајни суфицит масног ткива (апсолутно гледано 2.12 кг масти више), а у исто време значајни дефицит чистог контрактилног тј. протеинског ткива (апсолутно гледано за 0.65 кг мање, Табела 1). Телесни статус где се БМИ налази у зони апсолутно нормалних вредности, али где постоји суфицит масне компоненте, а дефицит контрактилне свакако не представља пожељни модел телесне структуре, нарочито ако су у питању младе особе женског пола, студенткиње узраста од $22.5 \pm 1.9$ година.

Наиме, утврђено је да се са порастом индекса телесне масе (БМИ), односно телесне масе на рачун масне компоненте, значајно повећава здравствени ризик за пет хроничних незаразних 
болести и то: хипертензије, дијабетеса, хроничне болести бубрега, астме и артритиса. У ранијим истраживањима је утврђено да је преваленција за хипертензију и артритис код особа са вредностима БМИ од 24.0 до 25.0 на нивоу од 18.5 и 7.7 , док је код особа са вредностима БМИ од 30.0 до 31.0 на нивоу 30.7 и 11.7, респективно (Stommel and Schoenborn, 2010).

Такође, утврђено је да код жена вредност БМИ расте сам по себи са годинама живота, тако да се повећава константом од 1.82 кг $\mathrm{M}^{-2}$ по декади од 20. године до 50. године живота, односно да од просечне вредности од $21.3 \pm 1.9$ кг $\mathrm{M}^{-2}$ расте до $27.5 \pm 4.6$ кг $\mathrm{M}^{-2}$ у поменутом узрастном добу (Casey et al., 1992). Вероватноћа да ће нека женска особа бити са повећаним вредностима БМИ, такође расте статистички значајно са узрастом, тако да је корелација вредности БМИ између узраста од 50 година и 20 година на нивоу $\mathrm{p}=0.44$, 50 година и 30 година на нивоу $\mathrm{p}=0.80$, а 50 и 40 година на нивоу $\mathrm{p}=0.87$ (Casey et al., 1992).

Веома сличне резултате су утврдили и наши истраживачи, јер резултати студије која се бавила основним морфолошким показатељима одраслих је утврдила да се вредност БМИ код жена из Војводине узраста од 33.0 до 40.0 година налази у распону од $25.67 \pm 4.51$ кг $\mathrm{M}^{-2}$, где је преваленција жена са прекомерном телесном масом нешто преко $30.0 \%$, док је преваленција гојазности преко 16.0\% (Pavlica et al., 2008). Жене из Београда, узра-

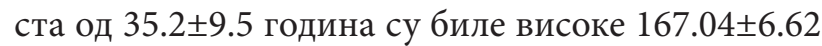
цм, тешке $67.66 \pm 13.39$ кг, са БМИ од $24.27 \pm 4.66$ кг $\mathrm{M}^{-2}$. Проценат мишићне масе код поменутог узорка је био $29.09 \pm 8.47 \%$, док је проценат масног ткива био $29.09 \pm 8.47 \%$, уз површину висцералне

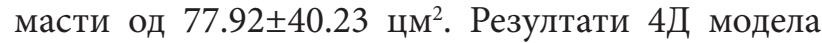
телесног састава је био следећи: маса воде је 34.58 Л или $51.11 \%$, маса протеина је 9.25 кг или $13.68 \%$, маса минерала је 3.30 кг или $4.88 \%$, а маса масти је 20.25 кг или 30.32\%. Утврђено је да постоји висок проценат жена у категорији предгојазних и гојазних и према критерију БМИ (око 40.0\%), као и према критерију Проц_БФ (око 36\%) (ĐorđevićNikić i sar., 2013).

Једна америчка студија, која се бавила променама телесне структуре код студената прве године студија, показала је да се и поред изврсних услова за физичко вежбања у оквиру колеџа, које су испитивани студенти имали, телесна маса код студенткиња у току прве године студија повећала за 1.28 кг, повећао се проценат масти у телу за $0.20 \%$, повећао се БМИ за 0.47 кг $\bullet \mathrm{M}^{-2}$, а такође се повећала и маса масти у телу за 0.43 кг (Hoffman et al., 2006). Друга студија је утврдила да се поред повећања свих варијабли морфолошког статуса током прве године студија, и током летњег распуста наставља тренд повећања праћених морфолошких варијабли, где се телесна маса која се повећала за 1.3 кг током школске године повећала за 0.1 кг и преко распуста, док се проценат масти који је порастао током школске године за $0.9 \%$, порастао додатно чак за $1.7 \%$ и преко распуста, док се БМИ за време распуста повећао за 0.8 кг॰м2 (Hull et al., 2007).

Утврђено је да телесна структура код студената статистички значајно корелира са степеном физичких активности, односно са нивоом метаболичке потрошње изражене у MET $\left(\mathrm{hrs} \bullet \mathrm{wk}^{-1}\right)$, и да управо ниво физичких активности обрнуто пропорцијално корелира са процентом масти у телу ( $\mathrm{p}=-0.40)$, односно са количином укупне масти у организму ( $\mathrm{p}=-0.26)$ (Zanovec et al., 2009). Такође, промене у телесној структури ка повећању вредности БМИ, повећању процента телесних масти, или смањењу масе контрактилне компоненте (протеини и скелетни мишићи) негативно утичу на стање општих и специфичних физичких способности, а промене повећања телесне масе и процента масти са смањењем нивоа аеробне издржљивости, као негативне адаптације на седентарни начин живота, много се више уочава код иницијално мршавијих студената, него код оних који су на студије већ дошли са натпросечним телесним статусом (Meckel et al., 2011).

У односу на узорак студенткиња Криминалистичко-полицијске академије из Београда код којих је утврђена преваленција гојазности од само $12.50 \%$ (у односу на критеријум Проц_БФ већи од $30.0 \%)$, код нашег испитиваног узорка је иста преваленција била 29.60\%, што је 2.37 пута више и много је сличније преваленцији студентске популације у Америци (од 20\%, Hull et al., 2007), односно студентској популацији у Израелу (од 29.9\%, Meckel et al., 2011).

Са почетком трећег миленијума уочен је нови феномен, нарочито код младе женске популације, а то је тенденција ка „мршавом“ изгледу (Cheney, 2011), где је због различитих хабитуалних, нутритивних и социо фактора дошло до појаве феномена новог телесног статуса. Наиме, методолошким 
приступом укрштања два критерија гојазности (БМИ и \%БФ), уочен је профил нове подкласе морфолошког статуса (Romero-Corall et al., 2008), а то је: мршаво - масне особе (skinny or and lean fat), односно особе које су потхрањене (skinny) или имају нормалне (lean) вредности БМИ, али истовремено и висок ниво процента масти у телу. Најновија истраживања о студентској популацији Београдског универзитета су показала да је преваленција у односу на категорију потхрањено - масне на нивоу од $1.07 \%$, док је у односу на категорију нормално - масне на нивоу од $6.59 \%$ (Dopsaj, 2018). У односу на податке из актуелне студије, дата преваленција код студенткиња ФАСПЕРА је за потхрањено - масне на нивоу од $1.6 \%$, док је за категорију нормално - масне на нивоу од $10.4 \%$. Другим речима, укупна преваленца за категорију мршаво - масне особе је била на нивоу од $12.0 \%$ (14 од 125$)$.

Генерално посматрано, телесна структура испитиваних студенткиња ФАСПЕРА, где постоји суфуцит компоненте масног ткива од 3.20 кг, уз дефицит контрактилне компоненте од 3.36 кг (Тaбела 1) само указује на очигледни квалитативни и квантитативни дисбаланс начина исхране, ка повећаном енергетском уносу, и то вероватно претежно из категорије “брзе хране“ или „слатке хране“, а смањеној енергетској потрошњи, и то нарочито усмереној ка дефициту систематског вежбања које последично повећава метаболизам масти и синтезе протеина, тј. вежбање са неким од типова додатног оптерећења (фитнес или теретана). Утврђено је да чак и веома мали позитивни дневни енергетски баланс од само 2-3\% (око 112 Кцал/дневно) за последицу има повећање укупне ТМ код студенткиња по семестру за око 1.4 кг, односно око $0.70 \%$ од телесне масе, од чега се масна компонента повећава за 1.9 кг, односно за $2.60 \%$ (Hull et al., 2007).

На жалост, на основу добијених резултата овог истраживања може се генерално закључити да је морфолошки статус студенткиња ФАСПЕРА из испитиваног узорка, на нивоу особа са нормалним БМИ (генерално нормално ухрањене), а са повећаним процентом масног ткива и смањеним процентом мишићног ткива. Овакав профил телесне структуре не представља адекватне вредности ухрањености као прихватљиве иницијалне морфолошке основе која обрзбеђује органско-метаболички статус младим женским особама по- требан за све професионалне и животне захтеве у будућности.

\section{ЗАКЉУЧАК}

На основу дистрибуције БМИ може се тврдити да је 77.60 \% испитаница у статусу нормалне ухрањености, али и да је укупна преваленција испитаница са прекомерном тежином (БМИ < $25.00)$ и гојазних на нивоу од $11.20 \%$, односно само преваленца гојазности (БМИ < 30.00) на нивоу од $4.17 \%$. Такође, утврђено је и да је преваленца недовољне ухрањености (БМИ > 18.50) $12.51 \%$, где је чак $3.13 \%$ испитаница и значајно неухрањено (БМИ > 17.50).

Утврђено је да чак 96.8 \% испитаница одступа од профила идеалне ухрањености. У односу на одступање у односу на дефицит, $63.2 \%$ испитаницаима има неки облик дефицита телесне масе (просек дефицита телесне масе од 5.20 кг) и то их има највише са дефицитом мишићне компоненте $78.4 \%$ (просек дефицита мишићне масе од 4.28 кг) у односу на дефицит масне компоненте 43.2\% (просек дефицита масне масе од 2.01 кг). Са профилом неког од суфицита има $33.6 \%$ испитаница (просечан суфицит телесне масе од 9.44 кг) где чак $54.4 \%$ има суфицит масне компоненте (на просечном нивоу суфицита масне масе од 7.48 кг). Нажалост, само $3.2 \%$ испитаница је имало оптималну телесну структуру у свим посматраним структурним сегментима.

Резултати 4Д модела телесне структуре студенткиња ФАСПЕРА се могу дефинисати на следећи начин: 31.75 Л воде (53.37\%), 8.50 кг протеина (14.26\%), 16.98 кг масти $(27.10 \%)$ и 3.10 кг минерала (5.18 \% од ТМ).

Поред постојеће вероватноће да је код студенткиња ФАСПЕРА начин исхране разлог за повећане масне компоненте, и чињеница да чак њих $69.6 \%$ уопште није физички активно, односно 21.6\% повремено, односно укупно 91.2\% није адекватно физички активно, указује на могући разлог зашто је код њих утврђен суфуцит масне компоненте, са једне стране, односно утврђен дефицит мишићне компоненте, са друге стране.

На жалост, на основу добијених резултата овог истраживања може се генерално закључити да је морфолошки статус испитиваних студенткиња 
ФАСПЕРА, на нивоу особа са нормалним БМИ (генерално нормално ухрањене), али са суфуцитом масног ткива и дефицитом мишићног ткива. Овакав профил телесне структуре не представља адекватне вредности ухрањености као прихватљиве иницијалне морфолошке основе која обезбеђује органско-метаболички статус младим женским особама потребан за све професионалне и животне захтеве у будућности.

\section{ЛИТЕРАТУРА}

1. Dopsaj, M. (2018). Body composition characteristics of the Belgrade university students defined by the multichanal bioimpedance method. U: Stanković V., Stojanović, T. (Ur.), The $5^{\text {th }}$ International Scientific Conference "Anthropological and Teo-Anthropological views on Physical Activity from the time of Constantine the Great to modern times", Kopaonik, 21.-24. mart 2018, Book of Abstracts (pp. 22-23), Univerzitet u Prištini, Leposavić: Fakultet sporta i fizičkog vaspitanja.

2. Dopsaj, M., Markovic, M., Kasum, G., Jovanovic, S., Koropanovski, N., Vukovic, M. \& Mudric, M. (2017). Discrimination of different body structure indexes of elite athletes in combat sports measured by multi frequency bioimpedance method. International Journal of Morphology, 35(1), 199-207.

3. Dopsaj, M., Ilić, V., Đorđević-Nikić, M., Vuković, M., Eminović, F., Macura, M., \& Ilić D. (2015). Descriptive model and gender dimorphism of body structure of physically active students of Belgrade University: Pilot study. Anthropologist, 19(1), 239-248.

4. Dopsaj, M., Todorov, I., Vuković, M., \& Radovanović, D. (2013). Various morphological indicators in elite judo athletes defined by multifrequency bioelectrical impedance analysis. Serbian Journal of Sports Sciences, 7(3), 129-141.

5. Dopsaj, M., i Dimitrijević, R. (2013). Klasifikacija studentkinja Kriminalističko-policijske akademije u odnosu na telesni sastav meren metodom multikanalne bioelektrične impedance. Nauka, Bezbednost, Policija - Žurnal za kriminalistiku i pravo, 18(1), 39-56.

\section{Напомена:}

Рад је део Пројекта „Ефекти примењене физичке активности на локомоторни, метаболички, психосоцијални и васпитни статус популације Републике Србије” под бројем III47015, а као део потпројекта "Ефекти примењене физичке активности на локомоторни метаболички психо-социјални и васпитни статус популације студената Републике Србије” који се финансира од стране Министарства просвете и науке Републике Србије - Циклус научних пројеката 20112019.

6. Допсај М, Благојевић М, Маринковић Б, Миљуш Д, Вучковић Г, Коропановски Н, Ивановић J, Атанасов Д, и Јанковић Р. (2010). Моделне карактеристике основних антропометријских показательа и базичномоторичких способности (БМС) здравих и утренираних младих особа оба пола популациони показатељи Р Србије. Криминалистичко-ролицијска академија: Београд.

7. Đorđević-Nikić, M., Dopsaj, M., Rakić, S., Subošić, D., Prebeg, G., Macura, M., Mlađan, D., i Kekić, D. (2013). Morfološki model populacije radno aktivnih žena Beograda meren metodom električne multikanalne bioimpedance: Pilot istraživanje. Fizička Kultura-Beograd, 67(2), 103112.

8. Zanovec, M., Lakkakula, A., \& Johnson, G.T. (2009). Physical activity is associated with percent body fat and body composition but not bady mass index in white and black college students. International Journal of Exercise and Science, 2(3), 175-185.

9. InBody 720 (2005). The precision body composition analyzer: User's Manual, 1996-2005 Biospace Co., Ltd., Korea: Gangam-gu, Seoul.

10. Jorga, J., Maksimović, M., i Davidović, D. (2007). Konvencionalno lečenje gojaznosti. Acta Clinica, 7(2), 79-94.

11. Kyle, U.G., Melzer, K., Kayser, B., Gremon, G., \& Pichard, C. (2006). Eight year longitudinal changes in body composition in healty Swiss adults. Journal of American College of Nutrition, 25(6), 493-501. 
12. Kyle, U.G., Schutz, Y., Dupertuis, Y., \& Pichard, C. (2003). Body composition interpretation: Contribution of the fat-free mass index and the body fat mass index. Nutrition, 19, 597-604.

13. Mott, J.W., Wang, J., Thornton, J.C., Allison, D.B., \& Heymsfield, SB (1999). Relation between body fat and age in 4 ethnic groups. American Journal of Clinical Nutrition, 69(5). 1007-1013.

14. Meckel, Y., Galily, Y., Nemet, D., \& Eliakim, A. (2011). Changes in weight indexes and aerobic fitness of physical education students over three years of college. Journal of Human Sports Exercises, 6(1).112-121.

15. Pavlica, T., Božić-Krstić, V., i Rakić, R. (2008). Body height and weight in adult population in Srem, Banat and Bačka (Vojvodina). Glasnik Antropološkog društva Srbije, 43, 329-335.

16. Romero-Corral. A, Lopez-Jimenez, F., SierraJohnson, J., \& Somers, V.K. (2008). Differentiating between body fat and lean mass-how should we measure obesity? Nature Clinical Practice. Endocrinology \& Metabolism, 4(6), 322-3.

17. Rothman, K.J. (2008). BMI - related errors in the measurement of obesity. International Journal of Obesity, 32, S56-S59.

18. Stommel, M., \& Schoenborn, C. (2010). Variations in BMI and prevalence of health risk in diverse racial and ethnic population. Obesity, 18, 1821-1826.
19. Hair, J., Anderson, R., Tatham, R., \& Black, W. (1998). Multivariate data analysis ( $5^{\text {th }} \mathrm{Ed}$.). New Jersey, USA: Prentice-Hall. Inc.

20. Hajnalka, P., i Čaba, P. (2017). Veza između stila života i statusa uhrnjenosti u populaciji adolescenata. Fizička Kultura-Baograd, 71(2), 145-153.

21. Heyward, V., \& Stolarczyk, L. (1996). Applied Body Composition Assessment. Champaign, IL: Human Kinetics.

22. Hull, H., Morrow, M., Heesch, K., Dinger, M., Han, J., \& Fields, D. (2007). Effects of the summer months on body weight and composition in college woman. Journals of Women's Health, 16(10), 1501-1515.

23. Hoffman, D., Policastro, P., Quick, V., \& Lee, S-K. (2006). Changes in body weight and fat mass of man and woman in the first year of college: A study of the "Freshman 15". Journal of American College Health, 55(1), 41-45.

24. Casey, V., Dwyer, J., Coleman, A., \& Valadian, I. (1992). Body mass index from childhood to middle age: a 50-y follow-up. American Journal of Clinical Nutrition, 56, 14-18.

25. Cheney, M.A. (2011). "Most girls want to be Skinny": Body (Dis)Satisfaction among ethnically diverse women. Qualitative Health Research, 21(10), 1347-1359.

26. World Health Organisation (2000). Obesity: Preventing and managing the global epidemic. Geneva: WHO Technical Report Series 894.

Примљен: 04.02.2018.

Прихваћен: 07.11. 2018.

Online објављен: 30.06.2019. 